\title{
The 1982 Guidelines and Preexisting Law
}

\author{
Donald I. Baker $\dagger$ \\ William Blumenthalł
}

\section{I \\ Guidelines AND The Judicial Process}

In promulgating enforcement guidelines, the Department of Justice tries to help the public predict the government's likely posture in particular future cases. But guidelines often have an implicit, secondary purpose as well: to tell the courts low they ought to decide cases, even where the Department is not a party. Whether the courts will histen is likely to turn, at least in part, on the extent to which the guidelines are perceived as deviating from the case law.

The 1982 Merger Guidelines ${ }^{1}$ present the issue of deviation more strikingly than have the Department's other guideline efforts, sucl as the 1968 Merger Guidelines, ${ }^{2}$ the 1977 Antitrust Guide for International Operations, ${ }^{3}$ and the 1980 Antitrust Guide for Joint Research Activities. ${ }^{4}$ Quite clearly, the 1982 Guidelines retreat significantly from many populist merger landinarks of the Warren Court era, as well they should. They rework the details of many stages of merger analysis, abandon certain theories of conglomerate violation, and apparently reject the relevance of social values to merger enforcement.

Nevertheless, the retreat is far from total. Horizontal mergers are still assessed under the basic metlodology of United States v. Philadelphia National Bank, ${ }^{5}$ under which the court first defines a relevant market and then draws conipetitive inferences from market sliares within it. To be sure, the Guidelines tinker with details: they try to improve

$\dagger$ Partner, Jones, Day, Reavis \& Pogue, Washington, D.C. A.B. 1957, Princeton University; B.A. in Law 1959, Cambridge University; LL.B. 1961, Harvard University.

$\ddagger$ Associate, Jones, Day, Reavis \& Pogue, Washington, D.C. B.A., M.A., 1977, Brown University; J.D. 1980, Harvard University.

1. U.S. Dep't of Justice, Merger Guidelines § I, 47 Fed. Reg. 28,493, 28,494 (1982), reprinted in 71 CALIF. L. REv. 649, 649-50 (1983) [hereinafter cited without cross-reference as Guidelines].

2. U.S. Dep't of Justice, Merger Guidelines-1968 (May 30, 1968), reprinted in 2 TRADE REG. REP. (CCH) ף 4510 (Aug. 9, 1982) [hereinafter cited as 1968 Guidelines].

3. U.S. Dep't of Justice, Antitrust Guide for International Operations (1977).

4. U.S. Dep't of Justice, Antitrust Guide Concerning Joint Research Ventures (1980).

5. 374 U.S. 321 (1963). 
the process of market definition, and they establish new statistical tests, calculated by means of a new index, from which to draw the imference of competitive effect. But these changes are comparatively mimor. The outcome of Philadelphia National Bank and many other leading cases would remaim the same under the new Guideline methodology.

Likewise, the Guidelines retain (and attempt to streamline) the theory of potential competition, despite its seeming emasculation in the Marine Bancorporation ${ }^{6}$ decision of 1974 . They also modestly reinvigorate policy on vertical mergers, from which the Department had retreated long ago without public announcement. ${ }^{7}$ The Guidelimes reiterate the hard, old-line prosecutorial positions on the "failing company" and "efficiency" defenses that the Warren Court cases and the 1968 Guidelines favored.

The Guidelines, then, are hardly a radical document. Virtually every provision deviates from precedent in some particular, however, and thus is exposed to the risk of judicial rejection. Excessive devotion to stare decisis would be unfortunate, for many of the Guidelines' deviations are well taken. This view is founded on two themes that pervade the discussion below.

First, case law has lagged behind the knowledge possessed by antitrust professionals-both because knowledge has progressed and because the Supreme Court lias been silent on substantive merger law since 1975. The new Guidelines have ennerged agamst a background of shifting social and economic thought, especially economic. Most economists today regard the merger standards eunbodied in the Warren Court cases as unduly restrictive and the market analyses of that era as inept. They would adopt alternative standards for defining markets, and they would recognize that mergers can serve a useful role in the process of capital formation. ${ }^{8}$ This is not to say that economists agree on exactly how markets sliould be defined or exactly how unuch the substantive rules slould be liberalized. ${ }^{9}$ Nonetheless, the 1982 Guide-

6. United States v. Marine Bancorp., 418 U.S. 602 (1974).

7. See infra note 103 and accompanying text; Edwards, Joffe, Kolasky, McGowan, Mendez-Penate, Ordover, Proger, Solomon \& Toepke, Proposed Revisions of the Justice Department's Merger Guidelines, 81 CoLUM. L. Rev. 1543, 1545 (1981).

8. See, e.g., X. Brozen, Mergers in Perspective 84 (1982) (mergers found to facilitate resource reallocation); McGee, Why Not "Deregulations" for Antitrust, in Industrial ConCENTRATION AND THE MARKET SYSTEM 63 (1979) (problems in market definition); F. SCHERER, Industrial Market Structure and Economic Performance 551 -56 (2d ed. 1980) (inconsistencies found in market definition approach in leading cases); cf. Mergers and Economic Concentration: Hearings on S. 600 Before the Subcomm. on Antitrust, Monopoly and Business Rights of the Sen. Comm. on the Judiciary, 96th Cong., 1st Sess. pt. 1, at 369-70 (1979) (statement of Sen. Adlai Stevenson urging adoption of world market approach) [hereinafter cited as Hearings on $S .600$ ].

9. Compare Hearings on S. 600, supra note 8, at 303-06 (statement of Dennis Mueller finding neutral effect of mergers on economic efficiency and urging Congress to base policy on noneconomic objectives) and id. pt. 2, at 134-42 (statement of F.M. Scherer to the same effect) with id. 
lines are in the mainstream of this imprecise consensus.

Although academic and professional thinking has advanced along these lines, it has not yet worked its way imto the Umited States Reports. The Supreme Court has not been given an opportunity to speak on substantive merger policy simce 1975 and thus has provided no precedent reflecting shifting economic currents. ${ }^{10}$ The Court's silence traces largely to the 1974 overhaul of the Expediting Act. ${ }^{11}$ Before then, Justice Department appeals of civil antitrust cases went directly to the Supreme Court; afterwards, the Department followed the usual appeal to the circuits. Meanwhile, the Department's 1974-75 defeats in General Dynamics, ${ }^{12}$ Marine Bancorporation, and Citizens \& Southern $\mathrm{Na}$ tional Bank ${ }^{13}$ and its de facto defeat in Connecticut National Bank ${ }^{14}$ apparently convinced the government to seek vimdication of section 7 law from forums other than the Supreme Court. The Justice Department has appealed merger cases to the courts of appeals, where it has won some ${ }^{15}$ and lost some, ${ }^{16}$ but it has not sought certiorari on substantive questions in a merger case since 1975. Similarly, the Solicitor General has not authorized any FTC appeal agamst the mounting merger reversals suffered by the Commission.

The second theme that pervades the discussion below is that the Guidelines must be viewed as a single framework with imteracting elements. In many instances, a Guideline provision deviates from the case law because a new twist is necessary for consistency. One can easily snipe at the Guidelines piece by piece. Taken as a whole, however, the Guidelines advance merger analysis by providing an imtellectual consistency that has been absent in the case law. This is not to argue that each individual line of the Guidelines is justified by the entirety. Some provisions are bad policy and would be bad law, and they can easily be pulled without unraveling the entire fabric. Our point is far less en-

pt. 1, at 419-23 (statement of Yale Brozen opposing new antimerger legislation due to resulting ecouomic inefficiencies) and id. at 428-31 (statenent of Jesse W. Markham to the same effect) and id. pt. 2, at 163, 257-62 (statement of George J. Benston to the same effect).

10. The Court has had opportunity outside of the merger context to take account of current economic thought, and it has responded by revising legal standards to reflect more modern analysis. See, e.g., Contmental T.V., Inc. v. GTE Sylvama Inc., 433 U.S. 36 (1977) (elimination of per se rule governing vertical nonprice restrictions).

11. Antitrust Procedures and Penalties Act-Expediting Act, Pub. L. No. 93-528, §4, 88 Stat. 1706, 1708 (1974) (codified at 15 U.S.C. $\$ 28$ (1976)).

12. United States v. General Dynamics Corp., 415 U.S. 486 (1974).

13. United States v. Citizens \& S. Nat'l Bank, 422 U.S. 86 (1975).

14. United States v. Counecticut Nat'l Bank, 418 U.S. 656 (1974).

15. E.g., United States v. Household Fin. Corp., 602 F.2d 1255 (7th Cir. 1979), cert. denied, 444 U.S. 1044 (1980). In addition, the governinent prevailed as appellee in United States v. CocaCola Bottling Co., 575 F.2d 222 (9th Cir.), cert. denied, 439 U.S. 959 (1978).

16. E.g., United States v. Siemens Corp., 621 F.2d 499 (2d Cir. 1980); United States v. International Harvester Co., 564 F.2d 769 (7th Cir. 1977). 
compassing: before rejecting a particular Guideline provision as deviating from narrow precedent, courts should inquire whether the provision is included to make analytic sense of the broader body of merger case law.

This last poimt is a serious concern, because the new Guidelimes deal in abstraction. They lack the specificity presented by a concrcte case. This abstract quality may make courts less willing to follow a Guidelines position that is at odds with a leading decided case. In a sense, this reality reflects our whole system of jurisprudence. The comunon law tradition is to build workable bodies of rules out of specific fact situations. The Guidelines, inore closely reseinbling the civil law tradition of fitting facts into preset rules, nnay seem less persuasive to a judge faced witlı a real controversy on a real factual record.

On the other liand, compared with the 1968 Guidelines, the 1982 effort provides a detailed explanation of the Department's thinking process. It also invites consideration of a much broader range of economic factors. Both of these changes unay cause busy judges to make greater use of the 1982 effort than they did of the 1968 effort. In any event, the 1982 Guidelines will be widely quoted in briefs for a long time to come. ${ }^{17}$

This is not to say that merger litigation will necessarily become simpler or more predictable. Mucl of the evidence that the government now holds important may be unobtamable in a probative form (and possibly in any form), particularly at the often-crucial preliminary injunction stage. Unsuccessful inquiries may prolong trials or frustrate judges and litigants. Yet by asking for a broader inquiry based on economically rational considerations, the Department will give the astute trial judge a better framework within whicls to organize the controversy before him.

In the renainder of this Article, we compare the elements of the Guidelines' franework witls the comparable elements in the case law. We first turn to the Guidelines' broad values and behavioral assumptions, where we observe that the Guidelines presume the ascendance of economic values over social and political values and adopt a collusion theory of economic conduct. We then examine the specifics of the Guidelines as to market definition and measurement and the analysis of competitive effects. Many of the specifics depart from the case law,

17. Although the 1968 Merger Guidelines were never regarded as binding, a number of courts gave thein considerable weight. See, e.g., Fruehauf Corp. v. FTC, 603 F.2d 345, 353-54 (2d Cir. 1979); Stanley Works v. FTC, 469 F.2d 498, 504 n.13, 505 n.16 (2d Cir. 1972), cert. denied, 412 U.S. 928 (1973); Crane Co. v. Harsco Corp., 509 F. Supp. 115, 124 n.6 (D. Del. 1981); United States v. Tracinda Inv. Corp., 477 F. Supp. 1093, 1108 (C.D. Cal. 1979); United States v. Hammermill Paper Co., 429 F. Supp. 1271, 1280 (W.D. Pa. 1977). 
although to widely varying degrees. The departures are generally well taken; a few are not. Most departures can generally be reconciled with the case law and the goals of the statute; a few cannot be.

II

\section{The Guidelines' Self-IMAge}

Every public policy docuunent, including enforcement guidelines, necessarily rests upon both value judgments and particular theories of human or business behavior. The new Merger Guidelines are reınarkably candid in laying bare these assumptions upon which they rest. They give economic values priority (perhaps exclusively so) over social and political values as a basis for section 7 pohicy. From among the inany conceivable economically based enforcement theories, the Department has plucked one of comparatively narrow (but hardly unanticipated) focus: inergers must not be permitted to enhance substantially the risk of tacit collusion. Although both the enforcement theory and the value structure in the Guidelines are generally consistent with the case law, they are likely to provoke sone dispute.

\section{A. Threatened Collusion as Theory of Enforcement}

In the new Guidelines, the Government has adopted a "conspiracy theory" of merger enforceınent. On this view, the principal risk associated with a merger is that it might better enable firms in the industry to conspire tacitly to increase prices and restrain production. This theory guides enforcement policy not only towards horizontal mergers, where it might be expected, but also towards vertical and conglomerate inergers.

By way of background, inerger policy during the 1960's tended to flow from a simple equation: increases in concentration lead to less efficient perfornance. In Philadelphia National Bank, ${ }^{18}$ for example, the Court spoke of "the inherently anticoinpetitive tendencies inamfested by these percentages." 19 Little effort was made to identify the precise transmission mechanism by which changes in inarket structure were converted into changes in economic performance. At times it seeined as if the focus of section 7 pohcy-and the evil proscribed

18. United States v. Philadelphia Nat'l Bank, 374 U.S. 321 (1963).

19. Id. at 366. Thus, for example, the Court wrote:

If the number of banks in the locality is reduced, the vigor of competition for filling the margimal small busmess borrower's needs is likely to diminish. At the same time his concomitantly greater difficulty in obtaining credit is likely to put him at a disadvantage vis-a-vis larger busimesses with which he competes. In this fashion, concentration im banking accelerates concentration generally.

Id. at $369-70$. 
under section 7-had shifted from the reduction of competition to increases im concentration per se.

The rationale for merger enforcement embodied in the new Guidelines is narrower. Under the Guidelines, the likelihood of enforcement is tied to the extent that the risk of collusion is significantly enhanced by a particular merger. ${ }^{20}$ In other words, the Guidelines view anticompetitive effects as flowing not from increased concentration per se, but from imcreased opportunities for collusion. Of course, concentration still matters: under the Guidelines, the principal enforcement tests are stated in terms of the nrarket's concentration and the amount it increases as a result of the subject merger. ${ }^{21}$ Unlike the 1960's cases, however, the Guidelines view concentration as mattering not for its own sake, but because it increases the hikelihood of collusion.

This is more a change in perspective than a change in policy. The old cases linked concentration to competitive performance by means of a slightly mysterious black box. The Guidelines provide greater analytic depth by offermg a view of the contents of the black box. That is, the Guidelines have given us an economic transmission mechanisin in the forin of collusion theory. Although that mechanism was never endorsed in the old cases as the principal theory of merger enforcement, it does find considerable support, particularly in Rome Cable, ${ }^{22}$ where the Court interpreted the logic of Philadelphia National Bank: "As [oligopoly] develops, the greater is the likelihood that parallel policies of mutual advantage, not competition, will emerge."23

Nonetleless, the shift in perspective should not be trivialized, for it las potentially far-reaching implications for the nature of the inquiry in inerger cases. The old cases' focus upon concentration was easily applied. Viewed in isolation, it sometimes led to erroneous conclusions, ${ }^{24}$ but it was accessible to judges, policymakers, businessmen, and

20. This thinking is set out in the introduction to the Guidelines. Guidelines $\S 1,47$ Fed. Reg. at 28,494, 71 CALIF. L. REv. at 649-50.

21. See infra note 86 and accompanying text.

22. United States v. Aluminum Co. of Am. (Roine Cable), 377 U.S. 271 (1964); cf. Tose v. First Pa. Bank, 648 F.2d 879 (3d Cir.) (discussion of "the old boy network of Philadelphia bankers"), cert. denied, 454 U.S. 893 (1981).

23. Rome Cable, 377 U.S. at 280.

24. By the early 1970's, economists were questioning the importance of concentration as the exclusive or even primary mdicator of narket performance. See gcnerally INDUSTRIAL CONCENTRATiON: The New Learning (H. Goldschmid, H. Mann \& J. Weston eds. 1974). Similar doubt is evident in United States v. General Dynamics Corp., 415 U.S. 486 (1974).

At the same time, there was increasing recognition that "mergers generally play an important role in a free enterprise econoiny. They can penalize ineffective inanagement and facilitate the efficient flow of investment capital and redeployment of existing produetive assets." Guidelines \$ I, 47 Fed. Reg. at 28,494, 7I CALIF. L. Rev. at 650. These beneficial effects were being lost in many instances because crude concentration analysis, as it was applied at the time, tended to overstate the competitive liarm of particular transactions. 
counselors alike. By refocusing on the inner workings of the black box, the new Guidelines invite consideration of numerous additional factors, all concerned with the ease of tacit collusion. ${ }^{25}$ This may complicate merger analysis and may increase the importance of formerly minor considerations.

\section{B. The Ascendance of Economic Values}

The new Guidelines are explicitly and unabashedly economic in approach. They are replete, for exainple, with standards based upon the measurement of elasticities. More generally, they would replace subjective judginent with economic tests wherever possible.

Soinewhat more subtly, the Guidelines are economic-as opposed to populist-in their values as well. Where economic, social, and political considerations once received more or less equal billing as the basis for merger policy, ${ }^{26}$ economic considerations have now achieved primacy. These Guidelines are directed alinost entirely at limiting the opportunity for tacit collusion among participants in a market. The grander and more generalized concerns of the past-viewing mergers as a threat to the societal fabric, for exainple ${ }^{27}$-have been discarded.

The Guidelines hardly represent a sudden shift on this point. To the contrary, they present a fair characterization of both the current case law and imtellectual trends. One might lament that fact and imstead wish that the social and political values embedded in the early case law and in the Clayton Act's legislative history had achieved prinacy. Indeed, one can imagine that but for several quirks of history, the case law might have evolved along those lines. But it didn't.

To see how far we have moved in the past twenty years, it is useful, and perhaps a bit sobering, to recall where we once stood. Describ-

25. The new Guidelines focus on, among other factors, product homogeneity (which makes collusion easier), any "gap" at the edge of the product or geographic markets (which makes collusion easier), and the availability of information on particular transactions (which makes eollusion more likely). The Guidelines also focus on the past history of collusion by means of various practices. Guidelines $\S \operatorname{III}(\mathrm{C}), 47$ Fed. Reg. at 28,498-99, 71 CALIF. L. REv. at 657-60; see also infra note 92 and accompanying text.

26. See, e.g., Corporate Merger Trends-Address by Attorney General, 5 TRADE Reg. Rep. (CCH) \ 50,107 (June 6, 1969) (address by Attorney Geueral Jolın N. Mitchell before the Gcorgia Bar Association, in Savannah); Reciprocity and Reciprocity Effects, 5 TRADE REG. REP. (CCH) I 50,110 (Aug. 12, 1969) (address by Roland W. Donnein, Antitrust Division Director of Policy Planning, before the Antitrust Law Section of the American Bar Association, in Dallas).

27. See, e.g., Brown Slioe Co. v. United States, 370 U.S. 294, 316 (referring to "Congress' fear ... of the threat to other values a trend toward conceutration was thought to pose"); $c f$. United States v. Aluminum Co. of Am. (Alcoa), 148 F.2d at 427 ("Many people beheve that possession of uncliallenged econonric power deadeus initiative, discourages thrift and depresses energy; that immunity from eompetition is a narcotic, and rivalry is a stimulant, to mdustrial progress . . . . It is possible, because of its indirect social or moral effect, to prefer a system of small producers...."). 
ing the Progressive Era, a critical period in the early development of antitrust policy, historian Richard Hofstadter wrote:

The progressive case against business organizations was not confined to economic considerations....

‥

At bottom, the central fear was fear of power and the greater the strength of an organized mterest the greater the anxiety it aroused. Hence it was the trusts, the investınent banking houses, the interlocking directorates, the swollen private fortunes that were most criticized ....28

Similar fears have been expressed throughout the history of antitrust, whether by Senator John Sherman in 1890 in connection with the adoption of the Sherman Act, or by Senator Estes Kefauver durimg the debates preceding the adoption of the Celler-Kefauver Act, ${ }^{29}$ which amended section 7 in 1950 with language that continues to govern antitrust aspects of inergers and acquisitions. ${ }^{30}$ The Supreme Court recognized this history in Brown Shoe, ${ }^{31}$ as did Judge Learned Hand in his famous Alcoa opinion. ${ }^{32}$ Populist sentiments may remain operative as law, at least in the sense that they have never been overruled. They continue to surface occasionally in modern opimions ${ }^{33}$ and may imfluence prosecutorial discretion. ${ }^{34}$

In terms of broad trends, however, the social and pohtical content of antitrust is intellectually passe, the rehc of another era. The primary emphasis in courtroom and classroom today is on econornic values, and this inainstream is reflected in the Guidehnes. Over the past decade the

28. R. Hofstadter, The AGe of Reform 225, 239 (1955).

29. See, e.g., 21 CONG. REC. $2457-60$ (1890) (statement of Sen. Sherman); 96 CoNG. REC. 16,448-56 (1950) (statement of Sen. Kefauver).

30. The language of the 1950 statute has been amended in minor respects by the Antitrust Procedural Improvements Act of 1980, Pub. L. No. 96-349, 94 Stat. 1154 (amending 15 U.S.C. $\S 18$ (1976 \& Supp. IV I980)).

31. 370 U.S. at $315-16$.

32. 148 F.2d 416, 427, 429 (2d Cir. 1945).

33. See United States v. Falstaff Brewing Corp., 410 U.S. 526, $540-43$ (1973) (Douglas, J., concurring in part); Crouse-Hinds Co. v. InterNorth, Inc., 518 F. Supp. 413, 421 n.7 (N.D.N.Y. 1980). See also Marathon Oil Co. v. Mobil Corp., 530 F. Supp. 315, 319 (N.D. Ohio), affd, 669 F.2d 378 (6th Cir. 1981), cert, denied, 102 S. Ct. 1490 (1982).

Populist values are somewhat more likely to be sounded outside of the inerger setting in monopolization cases, for example. See United States v. AT\&T, 552 F. Supp. 131 (D.D.C. 1982).

34. Antitrust Division officials, like other prosecutors, have always been influenced to some degree by factors that could loosely be labeled "social" or "political." When a decision is made to devote resources to investigate a particular sector of the economy, the implicit recognition is that the target area is "more important" than other potential uses for the same resources. One example might be mass media in general and horizontal mass media mergers in particular. See, e.g., Bureau of Competition, FTC, Proceedings of the Symposium on Media Concentration (1978). In this area, competitive values arguably lave importance going beyond provable economic effects, and it is rational for the Antitrust Division to devote resources to media cases im preference (at the margin) to other industries. 
support for populist values among intellectuals and policy makers has steadily eroded. Enforcement agencies have increasingly focused on the economics of particular transactions, and leading scholars liave increasingly denied the legitimacy of antitrust's social and political goals, albeit with soine dissent. ${ }^{35}$ Robert Bork expressed the sentiments of a generation of academic theorists when he declared: "The only legitimate goal of American antitrust law is the maximization of consumer welfare." 36 The thought was echoed by Richard Posner, Phillip Areeda and Donald Turner. ${ }^{37}$ Still others, somewhat more traditionally, contended that social considerations are, if not vapid and irrelevant, at least vague and unquantifiable. ${ }^{38}$ In day-to-day practice before the enforcement agencies, this contention has proved largely correct. Economics has provided decisionmakers with an accessible intellectual calculus often leading to relatively clear results. Sociology and political science, in contrast, have provided only generalities that are difficult to weigh when making enforcement decisions.

The trend away from populist sentiment has expanded well beyond academic circles and the enforcement agencies, however. It has also made substantial inroads into the judiciary. Many judges look to legal and economic scholars and to the enforcement agencies for leadership on antitrust questions. ${ }^{39}$ In addition, the shifting composition of the judiciary, particularly the Supreme Court, between the mid-1960's and the mid-1970's has brought more nonpopulist jurists to the bench. ${ }^{40}$ However one assigns cause, the result is clear: as the case law

35. Some leading scholars have continued to articulate and attempted to reinvigorate the social and political context of antitrust. Forenost among the scholars attempting to stem the economic tide are several participants in this Symposium. See Brodley, Limiting Conglomerate Mergers: The Need for Legislation, 40 OHo ST. L.J. 867 (1979); Fox, The Modernization of Antitrust: A New Equilibrium, 66 CoRnell L. Rev. 1140 (1981); Schwartz, "Justice" and Other NonEconomic Goals of Antitrust, 127 U. PA. L. Rev. 1076 (1979); Schwartz, Institutional Size and Individual Liberty: Authoritarian Aspects of Bigness, 55 Nw. U.L. Rev. 4 (1960); cf. Sullivan, Antitrust, Microeconomics, and Politics: Reflections on Some Recent Relationships, 68 CALIF. L. REv. 1 (1980) (courts giving predominant weight to efficiency justification should be prepared to defend that choice).

36. R. Bork, The Antitrust Paradox 51 (1978); accord GAF Corp. v. Eastman Kodak Co., 519 F. Supp. 1203, 1226 (S.D.N.Y. 1981).

37. See, e.g., R. Posner, Antitrust LaW 3-4 (1976); 1 P. Areeda \& D. Turner, AnTITRUST LAW III 100-113(c) (1976).

38. See, e.g., Hearings on S. 600, supra note 8, pt. 2, at 26 (statenent of William F. Baxter, then Professor of Law, Stanford University) (attacking objectives of legislative proposal as "abstract and inperceptible if not vacuous and nonexistent").

39. See supra note 17.

40. See, e.g., Fox, supra note 35, at 1143 n.8 ("A shift in the course of antitrust followed changes in the composition of the Supreme Court. Chief Justice Warren, Justices Black, Harlan and Fortas, and later Justice Douglas, retired. President Nixon appointed Harry A. Blackunun, Warren E. Burger, William H. Rehnquist, and Lewis F. Powell, Jr. President Ford appointed John Paul Stevens . . . Chief Justice Warren and Justices Black and Douglas [had been] particularly prominent in their articulation of power-dispersion as the primary goal of antitrust . . .."). 
has evolved since Brown Shoe, populist concerns have become largely vestigial. They inay still linger in the body of antitrust law, but as a practical matter they serve little function except to frnstrate clients who inust pay for legal advice and aberrant lawsuits. The key populist phrases of the Warren Court era have been muffled. ${ }^{41}$ Reviewing the trend in the case law, even those scliolars who would base antitrust policy in part on social and political considerations have been forced to admit the minority status of their views. ${ }^{42}$

Congressional intent also appears to have shifted since tlie passage of the Celler-Kefauver Act, although the nood of Congress is often difficult to track and is susceptible to sudden shifts with the prevailing political winds. Over the past decade, for example, numerous legislative proposals to restrict inerger activity have been advanced, ${ }^{43}$ generally with rationales articulated in populist terms. ${ }^{44}$ Only one of the

41. As best we have been able to determine from a quick LEXIS check, the Supreme Court last sounded the key populist phrases of Brown Shoe (i.e., retention of "local control" and "protection of small businesses," see 370 U.S. at 316) in 1974 in a dissenting opimion. See Gulf Oil Corp. v. Copp Paving Co., 419 U.S. 186, 207 (1974) (Douglas, J., dissenting). The only other time the phrases were sounded by the Court during the 1970's was in the concurrence in United States v. Falstaff Brewing Corp., 410 U.S. 526, 540-43 (1973) (Douglas, J., concurring in part). Before that, one must look to the dissent in United States v. Von's Grocery Co. No Circuit Court opimion has sounded the phrases since 1970-the last time was in United States Steel Corp. v. FTC, 426 F.2d 592, 601 (6th Cir. 1970).

The key populist phrases of Alcoa (i.e., concern over "great industrial combinations" and over the "moral or social effect" of small busimess, see supra notes 32-34 and accompanying text) have fared no better. The Supreme Court last voiced the phrases in Von's Grocery, 384 U.S. at 274-75. Lower courts have voiced the phrases only twice simce 1965, both times in dissents. See GTE Sylvania Inc. v. Continental T.V., Inc., 537 F.2d 980, 1021 (9th Cir. 1976) (Browning, J., dissenting), affd, 433 U.S. 36 (1977); Quinn v. Mobil Oil Co., 375 F.2d 273, $279-80$ (1st Cir.) (Aldrich, C.J., dissenting), cert. dismissed, 389 U.S. 801 (1967).

Of course, courts have continued occasionally to voice sinvilar notions, see supra note 33; but those occasions have grown fewer and fewer, particularly in the merger setting.

42. See Fox, supra note 35, at 1142-43 ("If there ever existed an antitrust policy to protect a society of sinall business units in spite of possible costs to the consumer, that policy has changed.") See also Sullivan, supra note 35, at 2-3 ("The Supreme Court is imcreasingly coinumitted to a conception of competition that einpliasizes efficiency as a dominant social value. This tendency is even more noticeable in lower court cases. Efficiency is not the only interest to which antitrust courts respond. But it is the primary one. Preoccupation with efficiency is changing the law . . . . In sun, antitrust courts today are expositors of applied microeconomic policy.").

43. See, e.g., National Petroleuin Supply Evaluation Act of 1981, H.R. 4930, 97th Cong., 1st Sess. (1981) [hereinafter cited as H.R. 4930]; Small and Independent Business Protection Act of 1979, S. 600, 96th Cong., 1st Sess. (1979); Oil Windfall Acquisition Act of 1979, S. 1246, 96th Cong., 1st Sess. (1979); Public Energy Competition Act, H.R. 8, 96th Cong., 1st Sess. (1979); Industrial Reorganization Act, S. 1167, 93d Cong., 1st Sess. (1973). See also C. KAYSEN \& D. TURNER, ANTITRUST POLICY 266-72 (1959) (earbier proposal to enforce restrictions on "unreasonable narket power").

44. See generally Mobil-Marathon and Similar Oil Company Mergers: Hearing on H.R. 4930 Before the Subcomm. on Fossil and Synthetic Fuels of the House Comm. on Energy and Commerce, 97th Cong., 1st Sess. (1981); Hearings on S. 600, supra note 8; Mergers and Industrial Concentration: Hearings Before the Subcomm, on Antitust and Monopoly of the Senate Comm. on the Judiciary, 95th Cong., 2d Sess. (1978). 
proposals, introduced under unique circumstances, came close to passage. ${ }^{45}$ Congress has not resisted testimony from antitrust enforcement officials that section 7 as currently interpreted by the courts has lost whatever social and political content it once had. ${ }^{46}$ Quite the contrary: it has acquiesced in the decline of antitrust populism. Moreover, it has thwarted the efforts of others to reinvigorate populist notions. When the FTC's enforcement practices became particularly zealous in the late 1970 's, for example, Congress quickly remed in the agency. ${ }^{47}$

In sum, the values inherent in the new Guidelines may depart from those expressed by Congress in 1950 and by the Supreme Court in the 1960's. But antitrust thinking has evolved considerably since then. The Guidelines' focus upon economic values and rejection of social and political values are consistent with recent case law under the Sherman Act and with the current deregulation-oriented political climate.

\section{III}

\section{Market Definition and Measurement}

Under the new Guidelines, as under the case law, one still analyzes a inerger in several discrete steps, first defining the relevant product and geographic markets, then assessing competitive effect within those markets, and finally asking whether any defense is available to save an otherwise unlawful transaction. Antitrust lawyers have become so inured to this analytical framework that they often fail to consider alternatives. The framework (more particularly, its multi-step character) is not pre-ordained, however. It is simply the most readily accessible means of determining whether a merger will create market power. In the sense that the frainework remains intact, the Guidelines are consistent with existing law. To the extent that the Guidelines depart from the past, those departures are limited to the individual provisions within the framework and to the way the provisions imteract.

45. That proposal, H.R. 4930, supra note 43 , was introduced principally in response to Mobil's efforts to acquire Marathon Oil in 1981. Had the takeover attempt not been blocked by the courts, see Marathon Oil Co. v. Mobil Corp., 669 F.2d 378 (6th Cir. 1981), cert. denied, 102 S. Ct. 1490 (1982), the legislation might well have passed.

46. See Hearings on S. 600, supra note 8, pt. 1, at 16 (1979) (statement of Michael Pertschuk, Chairman, Federal Trade Commission); id. at 61-62 (statement of John Shenefield, Assistant Attomey General, Antitrust Division, Department of Justice); id. at 136-44 (statement of Alfred F. Dougherty, Jr., Director, Bureau of Competition, Federal Trade Commission).

47. See Federal Trade Commission Improvements Act of 1980, Pub. L. No. 96-252, 94 Stat. 374 (codified in scattered sections of 15 U.S.C. (1976 \& Supp. IV 1980)); Oversight of the Federal Trade Comm'n. Hearings Before the Subcomm. for Consumers of the Sen. Comm. on Commerce, Science and Transp., 96th Cong., 1st Sess. (1979); Authorizations for the Federal Trade Comm'n and General Oversight Issues: Hearings on H.R. 2313 and H.R 2367 Before the Subcomm. on Consumer Protection and Fin. of the House Comm. on Interstate and Foreign Commerce, 96th Cong., 1st Sess. (1979); Senate Comm. on Commerce, Science and Transp., Federal Trade Commission ACt of 1979, S. Rep. No. 500, 96th Cong., 1st Sess. 2 (1979). 


\section{A. Market Definition}

Under the traditional merger jurisprudence of Philadelphia $\mathrm{Na}$ tional Bank $k^{48}$ and its progeny, market definition has been the crucial issue $\mathrm{m}$ the bulk of horizontal merger cases. ${ }^{49}$ Once one had identified the relevant market, then one needed only to calculate market shares, which were given nearly conclusive weight in determining legahty. More flexibility was introduced with General Dynamics; $; 0$ but even since that landmark decision, most horizontal merger cases have still been heavily litigated over questions of market definition. ${ }^{51}$

The 1982 Guidelines address market definition $m$ detail and, im so doing, probably make their inost important contribution to future inerger enforcement. ${ }^{52}$ As we explain below, the traditional approach suffers from numerous shortcomings, some of which are remedied by the Guidelines. While the Guidelines pose some new problems $s^{53}$ and fail to solve some old ones, ${ }^{54}$ they nonetheless represent an important

48. 374 U.S. 321 (1963).

49. Of course, market definition is crucial to non-horizontal cases as well, if for no other reason than for the conclusion that the merger is indeed non-horizontal and should therefore be analyzed under a different set of rules.

50. 415 U.S. 486 (1974).

51. See, e.g., Marathon Oil Co. v. Mobil Corp., 669 F.2d 378 (6th Cir. 1981), cert. denied, 102 S. Ct. 1490 (1982). In that case, the crucial question was whether the market for gasoline and other petroleum products was national in scope (as Mobil contended) or local and regional in scope (as Marathon contended and the court held).

52. Assistant Attorney General Baxter seems to have reached this same conclusion. See News \& Comment, 43 ANtitrust \& Trade Reg. Rep. (BNA) No. 1079, at 373 (Aug. 26, 1982).

53. Most of the new problems arise from the data called for under the various $5 \%$ tests set forth in the Guidelines. First, as a practical matter, the necessary data will often be unavailable. This is especially true if one is attempting to estimate the supply responses of fringe competitors and potential entrants. Second, as a theoretical matter, the $5 \%$ tests make no sense when apphed to certain types of markets. Assuming that the Department continues to accept cluster markets as a valid legal concept, how is one to apply the 5\% test to that setting? Similarly, how is one to apply the test to products without a prevailing narket price, such as custom or highly teclunical goods for which contracts are generally set on the basis of competitive bids? Cf., e.g., Grumman Corp. v. LTV Corp., 665 F.2d 10 (2d Cir. 1981) (land-based traimers properly imcluded in carrier aircraft inarket).

54. Most prominently, the Guidelines' 5\% test is susceptible to the "Cellophane trap," the logical error committed in Umited States v. E.I. du Pont de Nemours \& Co. (Cellophane), 351 U.S. 377, 401-03 (1956), which may lead to perverse results under certain circumstances. In the Cellophane case, du Pont had kept both prices and profits on its teclunically superior product high, thus attracting numerous imperfect and less versatile substitutes. See Stocking \& Mueller, The Ccllophane Case and the New Competition, 45 AM. Econ. Rev. 29, $57-62$ (1955). Although du Pont enjoyed considerable market power, it was able to convince the Court that the relevant market was broad. Consequently, du Pont was not deemed a monopolist.

One may contrast Cellophane with Umited States v. Alumimum Co. of Am., 148 F.2d 416 (2d Cir. 1945), in which the technical pioneer producer of virgin aluminum ingots kept capacity up and prices and profits down, thus reducing the opportunities enjoyed by producers of high-cost aluminum or substitute metals. Alcoa faced hittle competition and was deemed a monopolist.

The contrast illustrates that pricing choices can control market definition and market sharc. Any firm that possesses market power enjoys two polar options (as well as a spectrum in between): 
step forward.

To understand why this is so, it is first necessary to refiect upon the role market definition is intended to serve. The central concern embodied in section 7 is the fear of abuse of market power. As a practical matter, direct measurement of market power is extraordimarily difficult. Instead, a two-step measurement process has evolved: first define the relevant market, and then look to market shares (as well as other factors) as a proxy for measuring power within it. As the first step in the process, market definition is simply an analytical construct enabling us to compensate for our inability to measure market power directly. ${ }^{55}$

Mindful of the role of market definition in an antitrust imquiry, the Guidelines' drafters would construct markets so as to facilitate the second step in measuring a merger's competitive effect; ${ }^{56}$ i.e., assessment of market power. In order to define the relevant product or geographic market, the Department will first identify a provisional market, based on the products of the merging firms and the shipment patterns of the firms and their closest competitors. The Department will keep expanding the market boundaries until it has identified a group of products and a geographic area sufficiently imsulated from competitive pressure that a hypothetical exclusive seller could profitably imcrease price 5\% from the "prevailing or likely future level" for one year. If the exclusive seller could not increase price profitably, because too many buyers would shift to substitute products or distant suppliers within a year, then the "provisional market" is too narrowly defined. Other products and suppliers act as a competitive check. Only if the exclusive seller could profitably increase price 5\% are the group of products and the geographic area sufficiently well insulated to be deemed a market.

(1) it may hold price down to a level that makes it difficult for substitute products or distant sellers to compete, or (2) it may allow price to rise to the point that substitute products and distant sellers become substantial factors in the market. The first optiou suggests a narrow market and great market share; the second option suggests the opposite. Yet the seller's market power is the same in both circumstances. Indeed, because great market share is more likely to yield a finding of monopolization (or perhaps too much market presence to be permitted to merge), we are more likely to punish the firm that has chosen to limit its exercise of market power.

This point has been lost on the traditional market definition process. Courts have generally accepted whatever price prevailed in the market as their basis for analysis.

The Guidelines, too, call for little or no analysis of price. This may make for bad decisions. If, for exainple, the parties to a proposed merger are nembers of a tight-knit oligopoly, they may already be pricing at monopoly levels, and any further price increase would be unprofitable. Applying the 5\% test in that situation would lead to expansion of the market boundaries and dilution of the perceived significance of existing market power. A $5 \%$ test makes sense only if the baseline for the lyypothetical price increase is the competitive price, not the prevailing price called for under the Guidelines. (Of course, determining the competitive price may not be easy.)

55. See R. Posner, supra note 37, at 125; L. SUllivan, HANDBOoK OF THE LAW OF ANTITRUST § 12, at 41 (1977).

56. Guidelines $\S$ II n.6, 47 Fed. Reg. at 28,494 n.6, 71 CALIF. L. REv. at 650 n.6. 
The Guidelines approach is not a radical departure from the traditional standards for market definition; but it is different enough, particularly as to geographic markets, that some judges may reject it as inconsistent with precedent. This would be unfortunate, for the Guidelines are true to the goals and guiding principles of the case law, yet resolve and correct the incoherencies that have plagued market definition for the last two decades.

The differences are slightest as to product markets. Brown Shoe, the Rosetta Stone of market definition, declared: "The outer boundaries of a product inarket are determined by the reasonable interchangeability of use or the cross-elasticity of deinand between the product itself and substitutes for it."57 This in essence is what the Guidelines do. But the Guidelines add two related, critical features not addressed in Brown Shoe: the degree of interchangeability, and the time dimension. If products are so different that a $5 \%$ price shift would not lead to substitution within one year, the products are not interchangeable enough to fall within the boundaries of the same market. This does not undermine Brown Shoe. It simply injects an element neglected im the case, but necessary to give ineaningful content to any elasticity-based standard.

If the Guidelines' approach to product markets strays from the case law, it is in the selection of "5\%" and "one year" as the Guidelines' standards. Are these the proper degree of interchangeability and the proper time frame under the case law? To attempt to answer the question is to explain why the Guidelines represent an advancement. Taken as a whole, the case law offers neither sensible counsel nor a coherent pattern as to the necessary interchangeability within a welldefined market. Too many markets have been defined on the basis of ad hoc evidentiary selection, hand-waving, or result orientation. Notwithstanding the economic inquiry implicit in the Brown Shoe approach, the case law is seriously devoid of rigorous economic content. The Guidelines are to be applauded for filling this vacuum in the case law and finally offering a standard of measurement.

Those concerned with the laxity of the Guidelines should note that the "5\%/one year" standards hardly pose an open imvitation to merge. In our experience, businessmen routinely regard themselves and their markets as coinpetitively constrained even when they enjoy substantially greater pricing flexibility. If the " $5 \%$ " quantitative test im fact supplants horseback testimonial judgments as the basis for market defi-

57. 370 U.S. at 325 . The Court also noted that "cross-elasticity of production facilities" may be important as well. Id. n.42. The issue of supply flexibility is discussed in greater detail infra note 67 and accompanying text. 
nition, we may well see narrower product markets than those to which we have become accustomed.

The same cannot be said for geographic markets, for here the Guidelines stray much further from the approach traditionally taken in the case law. But this is sound, for the traditional approach to geographic market definition has long been due for an overhaul.

Geographic niarkets have traditionally been defined by reference to two contradictory guiding principles. According to Brown Shoe, the "geographic market selected must . . . both 'correspond to the commercial realities' of the industry and be economically significant." 58 This seems an nidisputable ideal and is fine as far as it goes, but all too often it is paired with (or superseded by) the Tampa Electric ${ }^{59}$ test: the "area of effective competition in the known line of commerce must be charted by careful selection of the market area im which the seller operates, and to which the purchaser can practicably turn for supplies." 60 The Tampa Electric test has led courts to focus upon the shipment and purchase patterns of the parties to the merger transaction under scrutimy. This focus has been curiously inconsistent with the interchangeability and cross-elasticity notions that characterize product market definition and, inore importantly, has held the potential for designating geographic markets that bear no relation to the econonic power of the participants. The actions of a seller, for example, may be constrained by rivals located outside the area in which he operates. If the seller were to raise price, rivals might fiood in from the outside. Likewise, the seller might limit the market power of producers outside of his marketing area. In either case, the true geographic market is broader than the seller's area of operation because market power inside the area is limited by potential rivals outside the area, and vice versa.

By shiftimg the geographic market inquiry imto an elasticity framework, the Guidelines inject some economic sense imto the process. One can only hope that the courts will follow the Guidelines' lead. Such action, while deviating from the language of the classic cases, can and should be justified as necessary to satisfy the broader goals of the market definition process.

The Guidelines also seein to depart from the case law as they relate to submarkets. Surely the Guidelines fail to hew to the hallowed "practical indicia" of a submarket as set forth in Brown Shoe. ${ }^{61}$ None-

58. 370 U.S. at 336-37 (quoting American Crystal Sugar Co. v. Cuban-American Sugar Co., 152 F. Supp. 387, 398 (S.D.N.Y. 1957), affd, 259 F.2d 524 (2d Cir. 1958)).

59. Tampa Elec. Co. v. Nashville Coal Co., 365 U.S. 320 (1961).

60. Philadelphia Nat'l Bank, 374 U.S. at 359 (cmphasis in original) (quoting Tampa Electric, 365 U.S. at 327).

61. 370 U.S. at 325 . 
theless, the departure, while substantial, has merit. Submarkets are recognized in the Guidelines' market definition provisions in two ways. First, the Guidelines provide explicitly for "additional, narrower . . . inarkets oriented to the buyer groups subject to the exercise" of price discrimination. ${ }^{62}$ Second and inore subtly, several configurations of products or geographic areas might each satisfy the 5\% test. Presumably the narrower configuration would be akin to the submarket of the broader configuration.

More fundamentally, the need for submarkets is dimmished (some might say obviated) by the Guideline treatment of other issues of merger analysis. To understand this point, one must understand the role of submarkets in the overall scheme of merger analysis. Submarkets are best viewed as a partial accommodation to shortcomings in the two-step ineasurement of economic power. Market definition is, in essence, the artificial creation of a magic grouping of transactions around which a circle is drawn. Under traditional approaches the circle is impermeable-everything inside is fully counted, and everything outside is ignored. In reality, the inarket power of a given producer is constrained to varying degrees by different rivals, depending upon how closely their products substitute for the producer's products and how close the rivals are geographically to the producer's marketing area. As Professor Sullivan notes: "economic relationships are seldom so simple that a relevant market can be defined with exactitude and confidence. There is not for any product a single, real 'market' waitmg to be discovered."63 Submarkets are a inechanism by which we take account of the fact that some products and areas are closer substitutes than others. It is worth nothing that the mechanisin is seriously deficient in that our standards of liability (e.g., market share thresholds) have not generally varied with the standard of substitutability to which products will be held before being placed in a simgle market or submarket. That is, we should be more tolerant of high market shares in a narrow submarket than in a broad narket, but we often have not been.

Yet submarkets are not the only mechanism by which to compensate for the "magic circle" character of market definition. One obvious alternative is to inake the circle permeable, permitting increments of market power to flow in and out depending on the closeness of sub-

62. Guidelines § II(A), 47 Fed. Reg. at 28,495, 71 CALIF. L. Rev. at 652.

63. L. Sullivan, supra note $55, \S 12$, at 41 . Judge Learned Hand made a similar point in Associated Press v. United States:

Most monopolies, like most patents, give control over only some means of production for which there is a substitute; the possessor enjoys an advantage over his competitors, but he can seldom shut them out altogether, his monopoly is measured by the handicap he can impose.

52 F. Supp. 362, 371 (S.D.N.Y. 1943), affd and quoted with approval, 326 U.S. 1, 17 n.17 (1945). 
stitutability. As a practical matter, this might be done by discounting the market shares of firms within the circle that are not head-to-head competitors. ${ }^{64}$ Similarly, the Guidelines achieve permeability by adjusting the market shares of committed and captive producers and by attributing competitive effect (as measured by market share) to potential rivals poised just beyond the circle.

In essence, the Guidelines have replaced submarkets with an alternative partial accommodation to the failings of market definition. The Guidelines' approach, while a departure from tradition, is not unprecedented. ${ }^{65}$ Quite the contrary, it appears to be the direction in which the case law has been heading. Permeable narkets are less stilted than submarkets and surely permit more accurate assessment of coinpetitive effects. We will be fortunate if the Guidelines hasten their evolution.

\section{B. Identification of Market Participants and Calculation of Market Share}

The identification of market participants and calculation of their market shares is vitally related to market definition. Indeed, the connection is so tight that one has traditionally spoken of a two-step merger analysis process (i.e., definition of market and assessinent of coinpetitive effect based presumptively upon shares within that inarket), as we have above, even though identification of narket participants and calculation of market shares are intermediate tasks that do not fiow autoinatically and mechanically from either step. That these intermediate tasks themselves require important and often difficult judginents is demonstrated by the Guidelines, which elevate thein to the same stature as inarket definition. Such intensity of analysis is itself an innocuous departure from the traditional approach. Potentially more troublesoine, the Guidelines offer some twists on, but not radical breaks from, both the traditional approach and its details. This is to be expected, however, froin drafters who have thought long and hard about difficult issues most often backhanded by the courts. And while the Guidelines unfortunately continue to backhand soine important issues and to address others imcompletely, their overall approach to identification of inarket participants and calculation of narket share is well-considered and, equally important, integrated with the other twists and minor deviations these Guidelines have taken from the traditional approach. In this set of issues, as elsewhere, it is necessary to view the Guidelines as a unitized framework.

64. E.g., Heublein, Inc., 96 F.T.C. $385,575-76$ (1980).

65. See id.; SKF Indus., 94 F.T.C. 6 (1979); Coca-Cola Bottling Co., 93 F.T.C. 110 (1979). 


\section{Identification of Market Participants}

The Guidelines would identify the following classes of firns as market participants: ${ }^{66}$

(1) firms that currently produce and sell the relevant product;

(2) firms whose existing production and distribution facilities could be shifted to enable the firm to produce and sell the relevant product within six months of a 5\% price increase;

(3) firms that recycle or recondition products that represent good substitutes for the relevant product; and

(4) vertically integrated firms that produce the relevant product for captive consumption.

The first class of participants-those currently producing and selling the relevant product-seens straightforward and beyond dispute. In contrast, the second class of inarket participants-those included by virtue of production flexibility-presents the greatest analytical twist im this section of the Guidelines. Under the traditional approach, production flexibility has nominally been taken into account in defining the market. The Brown Shoe Court, for example, noted that "cross-elasticity of production facilities inay also be an important factor in defining a product inarket." 67 Taken hiterally, the traditional approach suggests that if some production facilities can easily shift anong various products, then those products are in a single market, and every producer of any of the products is a participant in the inarket, even if other producers' facilities cannot easily shift. In contrast, the new Guidelines take production flexibility into account not for purposes of defining the inarket, but only for purposes of identifying market participants. Thus, the focus has shifted from the gross fiexibility of producers as a whole to the particular fiexibility of individual producers. Where production flexibility is feasible as a general matter, but several producers are incapable of shifting, the Guidelines will lead to greater inarket shares than faithful apphication of the traditional approach. Conversely, where production flexibility is not generally feasible, but several producers have unique teclinological abilities permitting them to shift, the Guidelines will lead to lesser inarket shares. In either case, the Guidelines are likely to yield a truer measurement of market power than faithful application of the traditional approach.

As a practical matter, the Guidelines' approach to production fiexibility is a substantial improvement over current practice, since the traditional approach has seldoin been faithfully apphed. As market definition has been practiced over the past two decades, production

66. Guidelines §II(B), 47 Fed. Reg. at 28,495, 71 CALIF. L. Rev. at 652-53.

67. 370 U.S. at 325 n.42. By its terms, the Court's statement was limited to vertical mergers, but that has never been regarded as a qualification of the imquiry into production flexibility. 
flexibility has played only a minor role. In Kaiser Aluminum \& Chemical Corp. v. FTC ${ }^{68}$ for example, the Seventh Circuit ruled that production flexibility alone, in the absence of a showing of interchangeability of end use, cannot support a inarket finding. ${ }^{69}$ While this position is tenable and perhaps even desirable as a basis for delineating a inarket boundary, it is likely to lead to perverse results if the boundary is impermeable, as it traditionally has been. Existing producers' pricing flexibility is clearly limited by the threat that new rivals inay be enticed to enter the inarket by higher prices and prospective profits. While such new rivals inay spring froin anywhere (and hence the frequent concern with entry barriers), they are nost likely to be drawn, in the short run, froin inanufacturers whose existing equipinent could easily be converted (or occasionally is converted) to produce the product in question. To ignore this source of competitive pressure is to attribute to existing inarket participants greater power than they actually have. The Guidelines offer a simple solution that manages to reconcile the cominon articulation of the traditional approach with the cominon apphication of the approach. If the Guidelines conform strictly to neither, that is because the traditional approach does not conform to itself.

By coinparison to the importance of the Guidelines' treatment of production flexibility, the issues raised by the third and fourth classes of market participants-recyclers and captive uses-are minor. For both classes, the law has been mixed as to whether they are properly included among inarket participants. ${ }^{70}$ The prevailing view seems to be the Alcoa $^{71}$ fornulation-recyclers are excluded; captive users are

68. 652 F.2d 1324, 1332 (7th Cir. 1981).

69. See also Reynolds Metals Co. v. FTC, 309 F.2d 223 (D.C. Cir. 1962) (Burger, J.) (although manufacturers of decorative foil could convert existing facilities to prodnce florist foil, they were not part of florist foil market); Umited States v. Black \& Decker Mfg. Co., 430 F. Supp. 729 (D. Md. 1976) (production flexibility treated as one of numerous factors in delineating submarkets); $\mathscr{~ f . ~ L . G . ~ B a l f o u r ~ C o . ~ v . ~ F T C , ~ 4 4 2 ~ F . 2 d ~} 1$ (7th Cir. 1971) (production flexibility rejected as basis for market definition im monopolization setting). But of. Spectrofuge Corp. v. Beckman Instrumeuts, 1nc., 575 F.2d 256 (5th Cir. 1978) (consideration of production flexibility im nonmerger settimg), cert. denied, 440 U.S. 939 (1979); Twin City Sportservice, Inc. v. Cliarles O. Finley \& Co., 512 F.2d 1264 (9th Cir. 1975) (same), cert. denied, 103 S. Ct. 364 (1982); Telex Corp. v. IBM, 510 F.2d 894 (10th Cir.) (same), cert. dismissed, 423 U.S. 802 (1975). See generally Note, The Role of Supply Substitutability in Defining the Relevant Product Market, 65 V.. L. Rev. 129 (1979) (reviewing cases and discerning trend towards acceptance of production flexibility by the courts).

70. Compare, e.g., Alcoa, 148 F.2d at 424 (production for captive use included in calculating market share) and United States v. Amax, Inc., 402 F. Supp. 956 (D. Conn. 1975) (production on toll included) with, e.g., Grumman Corp. v. LTV Corp., 665 F.2d 10 (2d Cir. 1981) (production for captive use excluded im calculating inarket share, at least at preliminary injunction stage of litigation), affg 527 F. Supp. 86 (E.D.N.Y. 1981) and Crane Co. v. Harsco Corp., 509 F. Supp. 115 (D. Del. 1981) (production for captive use excluded); compare, e.g., Alcoa (no independent significance attributed to producers of secondary product) with RSR Corp., 88 F.T.C. 800 (1976) (indepeudent signiflcance attributed to producers of secondary product).

71. 148 F.2d 416 (2d Cir. 1945). Support for the Alcoa treatment of captive production is 
included-but contrary views can find support. For the purpose of assessing market power, the Guidelines are correct in viewing captive users as market participants. Whether they are correct as to recyclers is less clear. The answer seems to be that recyclers should be included from a short-term perspective, but possibly not from a long-term perspective. $^{72}$

\section{Calculation of Market Share}

The Guideline provisions governing the calculation of market share are laced with ambiguity and uncertainty. For the most part, one cannot say whether the Guidelines adhere to existing law, for they either take no position or are ambiguously worded.

The Guidelines, for example, state that market shares should be 1neasured "in terms of dollar sales, physical unit sales, physical capacity, or (in natural resource industries) physical reserves"-whichever is the best indicator. ${ }^{73}$ All of these bases for measurement find some support in the case law, and use of the best one is certainly unobjectionable. (Litigants, of course, will differ over what indication is best $\mathrm{m}$ a given case.) As an expression of policy, the Guidelines do not depart froni the case law-because the Guidelines express no policy on the point at all.

We are also told that the "Department normally will mclude in the niarket the total sales or capacity of all firms (or plants) that are identified as being in the market."74 If this nieans what it seems to say, ${ }^{75}$ it will be a radical departure froin past practices. Rather than counting

more widespread than for the treatment of secondary product. See, e.g., 2 P. AREEDA \& D. TURNER, ANTITRUST LAW II 530 (1978).

72. The exclusion of recyclers is based upon the proposition that because all recycled product is derived from original products, original producers could regulate the future supply of recycled product by controlling current production. The Alcoa court, for example, suggested that, in making current production decisions, the company would weigh its contribution to the future supply of secondary aluminum. See 148 F.2d at 425 . This view is unpersuasive as to the short term, during which original producers are unable to affect the availability of inputs (i.e., obsolete or discarded origmal product) used by recyclers. To the extent that original producers could influence that availability at all, it would have been through their production deeisions in an earlier time period. From this short-term perspective, then, the Guidelines' inclusion of recycled product seems correct. Over the long term, however, original producers have the power to affect the availability of inputs used by recyclers. Whether sueh a sophisticated business judgunent enters into the fornulation of production decisions is a factual question and is likely to vary from industry to industry. From this long-term perspective, the Guidelines' position may be open to question.

73. Guidelines § II(D) n.26, 47 Fed. Reg. at 28,496 n.26, 71 CALIF. L. REV. at 654 n.26.

74. Id. § II(D), 47 Fed. Reg. at 28,496, 71 CALIF. L. REv. at 654 (footnote omitted).

75. Interpreting the Guidelines on this point is somewhat like reading tea leaves. Nonetheless, in hight of the various qualifications that immediately follow the quoted language in the Guidelines, the Guidelines' drafters apparently meant to be taken literally on this point. The Guidelines take care to carve out exceptions for firms imcluded in the market by virtue of produc- 
only a firm's, say, sales of the relevant product in the relevant geographic market, the Guidelines seemingly would count the firm's total sales, wherever sold. ${ }^{76}$ This view has gained soine support among academicians, ${ }^{77}$ but finds meager basis in the case law. ${ }^{78}$

Finally, following the teachings of General Dynamics, the Guidelines recognize that inarket shares may misstate the competitive significance of soine firms and that adjustments should be made accordingly. This proposition is unobjectionable, but the Guidelines falter in offering no guidance as to how much adjustinent should be made and in what circumstances. In that sense they are true to existing law, but only because they duck the hard issue.

\section{IV \\ ANALYSIS OF COMPETITIVE EFFECTS}

A key practical question since 1950 has been how much evidence of inarket effect the government (or private plaintiff) must prove to block a merger under section 7 . The statute's celebrated imcipiency language invites lower standards of proof, but the precise formulation has long been in fiux.

During the Warren Court era, there seeined a general presumption that mergers were, if not bad, at least suspect. Heavily populist im orientation, this presumption reflected concern over concentration in the abstract and over the perceived loss of small-town and small-firm val-

tion substitution and internal consumption; for them, shares will be based upon the relevant geographic market only. See id. This suggests different treatment for everyone else.

Whether the Department follows the Guidelines on this poimt is another issue. We understand that in early analyses under the Guidelines, the Department has calculated the shares of existing market participants based upon the relevant product in the relevant geographic market. See, e.g., Complaimt, United States v. Stroh Brewery Co., No. Civ. 82-1059 (D.D.C. filed Apr. 16, 1982), reported in 4 TRADE REG. REP. (CCH) If 45,082, at 53,538-39 (Jan. 31, 1983).

76. Read even more literally, the Guidelines would base each participant's market share on its total sales of all products (not just the relevant product) in all areas (not just the relevant geographic area). But this surely is not the intention of the Guidelines' drafters. Sucl an approach would convert horizontal merger analysis imto, essentially, a conglomerate inquiryhardly the approach to be endorsed by those who have done away with the entrenchment theory of $\$ 7$ violation, see infra note 107 and accompanying text.

77. See Laindes \& Posner, Market Power in Antitrust Cases, 94 Harv. L. Rev. 937 (1981). But see Brennan, Mistaken Elasticities and Misleading Rules, 95 HARv. L. Rev. 1849 (1982).

78. Courts have occasionally looked to the total activity of market participants, but lave generally done so within the context of a world market. See, e.g., United States v. Tracinda Inv. Corp., 477 F. Supp. 1093 (C.D. Cal. 1979); Honeywell Inc. v. Sperry Rand Corp., 180 U.S.P.Q. (BNA) 673 (D. Minn. 1973); United States v. Standard Oil Co. (N.J.), 253 F. Supp. 196 (D.N.J. 1966). In at least one instance, lowever, a court looked to total supply outside of a narrower market. See United States v. Standard Oil Co. (Ind.), 1964 Trade Cas. (CCH) I 71,215, at 79,847, 79,865 (N.D. Cal.) (although the "Umited States is the relevant market . . ," the "total supply to which competing refiners may and do turn for their raw materials is the Free World crude oil and production and reserves" except as limited by the government). 
ues in society. With this concern the majority permitted the government to prevail on the basis of statistical presumptions or minimal proof in support of interesting theories.

In contrast, the Burger Court has raised the government's standard of proof and has granted defendants wider latitude in rebutting a prima facie case. However, while the trend is clear, the standard of proof is not. In the wake of General Dynamics and Marine Bancorporation, the state of the law is subject to a range of interpretations. At best, one can identify the inainstream.

The Guidelines fall within that mamstream in its treatinent of horizontal inergers. Although they depart from the case law and traditional practices in several details, their approach is consistent with the line of decisions since Philadelphia National Bank. In contrast, the Guidelines are more adventuresone in their approach towards vertical and congloinerate inergers. There, more than in any other provisions, the Guidelines risk rejection by the courts.

\section{A. Horizontal Mergers}

The Guidelines adhere fairly closely to the current state of the law on the standards by which horizontal mergers are to be judged. To be sure, there are cosinetic differences. The Herfindahl-Hirschman Index (HHI) has replaced the four-firm concentration ratio, and non-share factors have been given an exphicit description, although probably not any greater importance than they have recently enjoyed. There are minor substantive differences, too: the statistical standards have been loosened from those that prevailed in the mid-1960's (but less so from those that prevailed circa 1980). But these changes are hardly foundation for complaint. This section of the Guidelines is an accurate reflection of the government's enforcement policies-not only under the present administration, but as the policies have stood for sone time. Our understanding of industrial organization has undergone considerable evolution since the time of Von's Grocery, ${ }^{79}$ Pabst,${ }^{80}$ and Continental Can; ${ }^{81}$ if these Guidelines are not true to those cases, it is only because antitrust officials have been backpedalling for at least fifteen years. ${ }^{82}$

79. United States v. Von's Grocery Co., 384 U.S. 270 (1966).

80. United States v. Pabst Brewing Co., 384 U.S. 546 (1966).

81. United States v. Continental Can Co., 378 U.S. 441 (1964).

82. The backpedalling began almost immediately. The 1968 Merger Guidelimes, for example, were looser than the leading cases of the Warren Court era. It is also imstructive to observe how the views of the individuals behind the leading populist cases of the 1960's have changed. For example, Riclaard Posner, archetype of the Chicago School, briefed Pabst, see 384 U.S. at 547, and argued Von's Grocery, see 384 U.S. at 271. Similar instances of recanting are recounted in Brozen, The Concentration-Collusion Doctrine, in Industrial CONCENTRATION AND THE MARKET SYSTEM 92 n.8 (1979). 
The fundamental principles governing analysis of competitive effect trace back to Philadelphia National Bank, where the Supreme Court adopted a presumption of illegahity on the basis of market share percentages. ${ }^{83}$ To a degree which remains unclear, ${ }^{84}$ the Court retreated from this reliance on market share in General Dynamics. Courts since General Dynamics have continued to rely primarily on inarket shares and concentration in assessing competitive effects, but have been willing to look to other factors as well, in some instances ignoring statistical inferences in hight of other evidence. ${ }^{85}$

The Guidelines are faithful to this approach. They draw inferences based principally on statistical evidence, but look to other factors in close or exceptional cases. ${ }^{86}$

Of course, the Guidelines' statistical tests are not based upon fourfirm concentration ratios and the merging parties' market shares; they are instead based on the HHI and the imcrease in the HHI resulting from the transaction. To highlight this switch as a departure from precedent, as some litigants no doubt will, would be petty and fatuous. The HHI and the more traditional four-firm concentration ratio are

83. Philadelphia Nat' Bank, 374 U.S. at 362. The Philadelphia Nat' Bank approach owes a substantial intellectual debt to Bok, Section 7 of the Clayton Act and the Merging of Law and Economics, 74 HARv. L. Rev. 226 (1960), which advocated a test for prima facie unlawfulness based principally upon the increase in market concentration resulting from a merger. Professor Bok was at odds on this score with some of his contemporaries. See, e.g., REPORT OF THE ATrORNey General's National Commitree to Study the Antitrust Laws 123 (1955) ("No one pattern of proof can meet the requirements of all cases . . . Thus, it will always be necessary to analyze the effect of the merger on relevant markets in sufficient detail, given the circumstances of each, to permit a reasonable conclusion as to its effect.") (emphasis added) [heremafter cited as 1955 ATTORNEY GENERAL's REPORT]. The Report then identified more than fifty factors to be considered in analyzing the effect of a merger.

Professor Bok severely criticized the Report's "dizzying list of factors." In his view, "there is definite value in formulating merger rules which will be predictable and susceptible of being administered without lieavy burdens in time and expense." Bok, supra, at 271. It was this view that prevailed in Philadelphia Nat"l Bank.

84. General Dynamics, 415 U.S. at 497-98. Commentators have offered numerous, widely varying interpretations of the significance of General Dynamics. See, e.g., Moyer, United States v. General Dynamics Corporation: An Interpretation, 20 ANTITrust BuLL. 1 (1975); Posner, Antitrust Policy and the Supreme Court: An Analysis of the Restricted Distribution, Horizontal Merger and Potential Competition Decisions, 75 Colum. L. Rev. 282 (1975); Robinson, Recent Antitrust Developments: 1974, 75 Colum. L. Rev. 243 (1975); Shenefield, Annual Survey of Antitrust Developments-Class Actions, Mergers, and Market Definition: A New Trend Toward Neutrality, 32 WASH. \& Lee L. Rev. 299 (1975); Note, Horizontal Mergers After United States v. General Dynamics Corp., 92 Harv. L. Rev. 491 (1978).

85. See, e.g., United States v. International Harvester Co., 564 F.2d 769 (7th Cir. 1977).

86. The Guidelines' approach in this regard may profitably be contrasted with the approach taken by the Federal Trade Commission in FTC, Statement Concerning Horizontal Mergers (June 14, 1982), reprinted in TRADE REG. REP. (CCH) No. 546, at 71 (June 16, 1982) (special supplement to 2 TRADE REG. REP. (CCH) ๆ 4225 (Aug. 9, 1982)) [hereinafter cited as FTC Statement]. The FTC Statement barrages the reader with numerous nonstatistical factors to be taken into account in merger analysis and liarks back to the 1955 ATTORNEY GENERAL's REPORT, supra note 83. 
simply alternative measures of market concentration. They tend to track each other closely. ${ }^{87}$ To the extent one must select the better measure of market power, most economists seem to prefer the HHI, ${ }^{88}$ although it is not without its shortcomings. ${ }^{89}$ As a practical matter, the switch is unlikely to affect the outcome of cases (unless judges are tricked into disregarding HHI evidence as contrary to precedent). Had the HHI standards set forth in the Guidelines been applied during the Warren Court era, most of the leadimg merger cases would have reached the same result. ${ }^{90}$ This point is illustrated in Table I.

Another petty objection that might be voiced concerns the Guidelines' use of "other factors," but here, too, the Guidelines are reasonably faithful to the case law. This conclusion hinges on a centrist interpretation of General Dynamics. If one were to view General Dynamics as mandating a full-blown inquiry imto every economic variable affecting competition in the relevant market, then the Guideline approach to nonstatistical factors would be too narrow. On the other extreme, if one were to view General Dynamics as an aberrant case

87. See F. SCHERER, supra note 8, at 58 ("correlation between the four-firm sales concentra"tion ratio (the most commonly used of all measures) and the [HHI] was 0.936 "); Scarbrough \& Pfunder, New Merger Guidelines Not Always Less Restrictive, Legal Times (Washington), Jan. 10, 1983, at 19, col. I (graphing relationship between four-firm concentration ratio and HHI based on Monte Carlo simulations).

88. See, e.g., G. Stigler, The Organization of Industry 31-36, 261-62 (1968) ("theory suggests that a measure of the fluctuation of shares . . . of individual firms should be used, and such a measure can be approximated by the Herfindahl ineasure"); F. SCHERER, supra note 8, at 58 (deeming the HHI the "often-preferred" measure, but expressing reservations). The preference among economists for the HHI may have waned in recent years. In an earlier edition of his textbook, for example, Scherer wrote: "[T] the extent that monopoly power is correlated positively with both fewness of sellers and inequality in their sizes, the Herfindahl index comes close to being an ideal composite measure." Id. at 51-52 (1st ed. 1970). Scherer's view has since sofened: "How desirable or undesirable [the HHI's] weighting scheme is depends upon the relevant theory as to how market structure, conduct, and performance are related." $I d$. at 58 (2d ed. 1980).

89. Foremost among these shortcomings is that market share data for the largest sellers may not be available in sufficient abundance or at a sufficiently high level of aceuracy to calculate the HHI in a particular case. See F. SCHERER, supra note 8, at 58 (2d ed. 1980).

The HHI may also lead to erroneous structural conclusions. We thank George Hay for providing the following illustration comparing two market structures: one market consists of five firms, each with a $20 \%$ share; a second inarket consists of flve firms with shares of $30 \%, 20 \%, 20 \%$, $20 \%$, and $10 \%$. The $\mathrm{HHI}$ would predict that the second market is more susceptible to collusion, yet this is probably wrong. Because firms in the second market are more likely to be dissimilar from one another (in terms of cost structure, distribution pattern, etc.), successful collusion annong them would probably be less likely. This is not a basis for rejecting the HHI in favor of four-firm concentration ratios, however, for the four-firm concentration ratio leads to the same erroneous inference.

90. See infra Table I, p. 335. Of the cases, only Von's Grocery would have come out differently under the Guideline's HHI Standards. Of course, this comparison assumes as given the markets defined in the various cases. Many of those markets appear in retrospect to have been gerrymandered or ill-defined. The results of the cases would have changed markedly if the markets had been properly defined. 


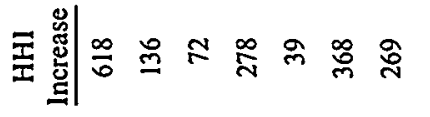

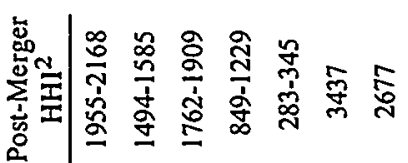

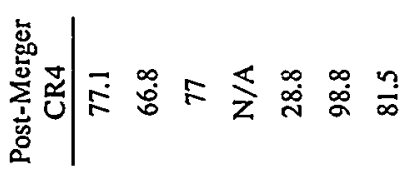

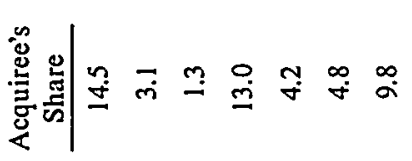

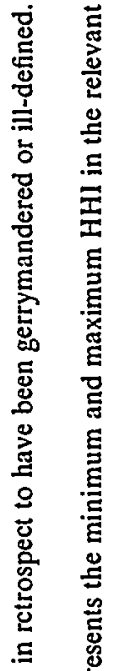

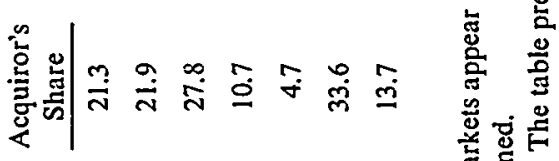

㘴

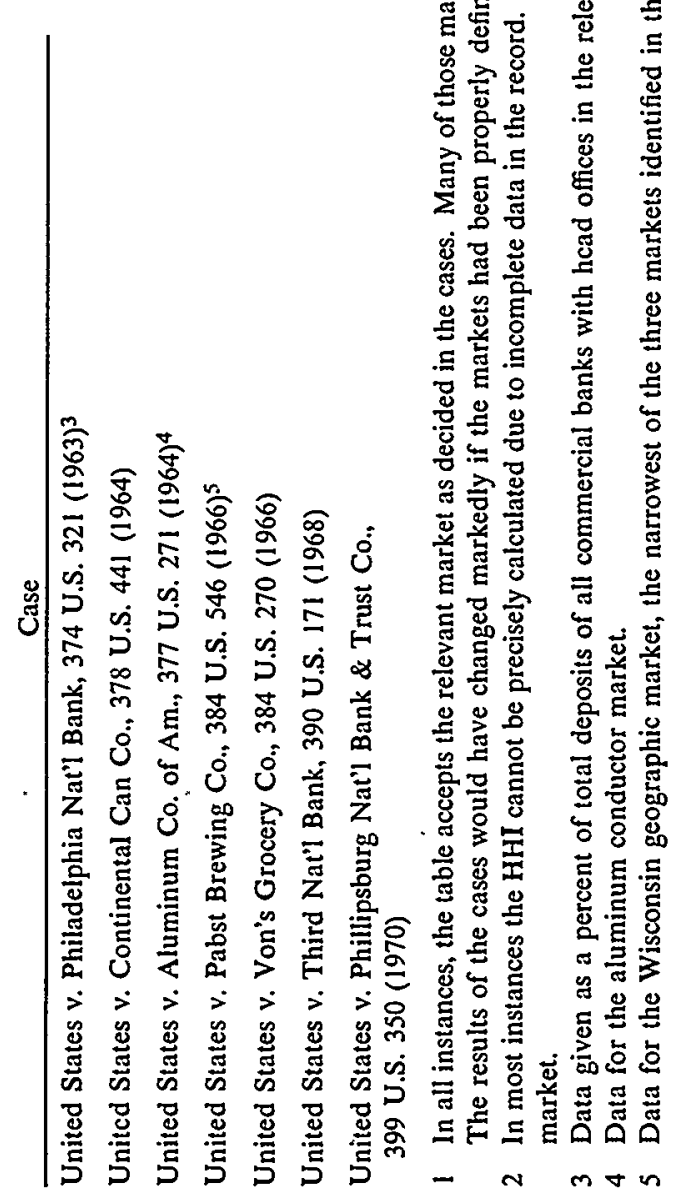


standing only for the proposition that market share measurements must bear some relation to competitive reality, then the Guideline approach is too broad. The current case law seems to stake out a middle ground: General Dynamics and Philadelphia National Bank, taken together, require the court to give primary deference to statistical considerations, but to inform its judgment by reference to the competitive reahties $m$ which the statistics arise. This is the course the Guidelines adopt.

Of course, one might quibble with the "other factors" that the Guidelines choose to emphasize. Entry barriers, traditionally the most important nonstatistical factor, receive highlighted treatment as a distinct Guideline provision, ${ }^{91}$ but on the whole scem to carry no greater analytical weight than some considerations which must be regarded as obscure. ${ }^{92}$ And some obvious "other factors" seem to have been overlooked. ${ }^{93}$ As a selection of relevant criteria, however, the "other factors" are a good assortment. Many have been recognized in the case law, and virtually all have been recognized by economists who are often cited in the case law. ${ }^{94}$

A more serious question is whether the Guidelines' statistical thresholds have been loosened to excess. Several facts are clear. The new Guidelines are substantially looser than the 1968 Guidelines as to unconcentrated industries, but they are only somewhat looser as to inoderately concentrated industries and marginally looser as to highly concentrated industries. The Guidelines are also looser than certain antitrust cases. ${ }^{95}$ Whether these facts are grounds for objection depends on one's vision of the role of Guidelines, the role of government policy makers, and the decay rate of bad precedent. The Guidelines accurately portray the government's enforcement intentions-imten-

91. Guidelines $\S \mathrm{III}(\mathrm{B}), 47$ Fed. Reg. at 28,498, 71 CALIF. L. REv. at 657.

92. It is useful to compare the Guidelines' treatment of entry barriers, id., with the Guidelines' treatment of other factors, such as the frequency and size of typical orders for the relevant product and the availability of information about specific transactions, id. $\S \operatorname{III}(C)(2), 47$ Fed. Reg. at 28,498-99, 71 CALIF. L. REv. at 659. Certainly these other factors are relevant, but they have not traditionally been the focus of merger analysis.

Under the Guidelines, neither entry barriers nor the other factors will affect the Department's decision whether to bring an enforcement action in unost cases. Entry barriers come into play only if they are very high or very low. Id. \$ IlI(B), 47 Fed. Reg. at 28,498, 71 CALIF. L. REv. at 657. Other factors come into play only in close cases. Id. $\$ \mathrm{III}(\mathrm{C}), 47 \mathrm{Fed}$. Reg. at 28,498, 71 CALIF. L. REV. at 657-58.

93. One might have supposed that the Guidelines would take account, for example, of buyer concentration and market growth.

94. See F. SCHERER, supra note 8, chs. 6, 7. These chapters, entitled Conditions Facilitating Oligopolistic Coordination and Conditions Limiting Oligopolistic Coordination, discuss such "other factors" as product homogeneity, availability of information about specific transactions, bunching and infrequency of orders, collusive agreements, and industry social structure.

95. See Von's Grocery, 384 U.S. 270 (1966); Stanley Works v. FTC, 469 F.2d 498 (2d Cir. 1972) (HHI increase of 44, postmerger HHI of approximately 1050), cert. denied, 412 U.S. 928 (1973). 
tions, it should be noted, that are hardly radical. We have already illustrated that the Guidelines are consistent even with the statistical thresholds set forth in the Warren Court's merger cases, except for the draconian Von's Grocery decision. ${ }^{96}$ And although the Guidelines' statistical thresholds may be looser than the government's enforcement standards of the past, they represent the end product of steady evolution over the course of successive administrations. ${ }^{97}$ Economic understanding has come far since the mid-1960's, and the standards that prevailed at the time of the 1968 Guidelines are fairly characterized as a relic of outmoded antitrust policy. The old enforcement standards (and certainly the Von's Grocery position) are stricter than necessary to fulfill the economic goals of section 7 and, in the process, hindered other policy interests. Some parties, particularly private plaintiffs, nay seek to resurrect the statistical thresholds of the past for their own gain, and on occasion sone lower courts may unwarily follow suit, but those who make pubhic policy are entirely proper in enforcing the law in hight of present-day understanding.

\section{B. Vertical Mergers}

The thrust of vertical merger law has traditionally been on foreclosure of the competitive opportumities of those who had to sell or buy in conipetition with the merged parties. It was feared that unintegrated sellers would be foreclosed from the sales opportunity presented by a newly integrated nerger buyer, or that an unintegrated buyer who had to rely on a newly integrated source of supply might suffer coinpetitive decline, particularly in times of shortage. In Brown Shoe the Supreme Court wrote:

The primary vice of a vertical merger or other arrangement tying a customer to a suppher is that, by foreclosing the competitors or either party from a segment of the market otherwise open to them, the arrangement may act as a "clog on competition," . . . which "deprive[s] . . . rivals of a fair opportunity to compete."98

That landmark decision suggested such low percentage tests of impermissible foreclosure that even the Department of Justice declined to adopt such strict tests in the 1968 Merger Guidelines. ${ }^{99}$ The Brown

96. See supra note 90 and accompanying Table and text. To the extent that the Guidelines deviate from the Warren Court's merger cases, they do so principally as to the standards governing market definition, see supra text accompanymg notes 55-65, vertical mergers, see infra text accompanymg notes $98-105$, and the reciprocity and entrenchment theories of challenge to conglounerate mergers, see infra notes 106-07 and accompanying text.

97. Even the 1968 Guidelines were looser than Von's Grocery, for exainple.

98. Brown Shoe, 370 U.S. at 323-24 (citations omitted).

99. In particular, the 1968 Guidelines set tests of $10 \%$ and $6 \%$ in the backward and forward markets, respectively, 1968 Guidelines, supra note 2, paras. 12-13, 2 TRADE REG. REP. (CCH) at 6886, compared with the Brown Shoe standards of $4 \%$ and $2 \%$. 
Shoe type of foreclosure theory has been subjected to increasing academic criticism, ${ }^{100}$ and, during the 1970's, the Department of Justice retreated from even the 1968 standards.

Indeed, the law of vertical mergers has been a dying letter for the last ten years, ever since the Supreme Court, in a last burst of 1960'stype antitrust populism, invoked vertical and conglomerate theories to block the Ford-Autolite merger in 1972. ${ }^{101}$ Challenges to vertical mergers simce then, by either the government or private parties, have been few in number. Prior to issuance of the Guidelines, the inost recent successful vertical merger case had been Hannischfeger's defense against a tender offer in $1979,{ }^{102}$ and the government had lost the few challenges it saw fit to bring. ${ }^{103}$

The Guidelines had been expected to articulate the final abandonment of Justice Department challenges to vertical inergers. ${ }^{104}$ Instead, surprisingly, they may have resuscitated the law in this area-largely by fashioning three new theories, two of which bear scant relation to the foreclosure theories of old.

The first theory is that vertical mergers inay lessen competition by increasing entry barriers. The Guidelines establish three preconditions to a challenge under this theory: (1) the merger must create the need for two-level entry, (2) the merger must increase the difficulty of simultaneous entry to both markets, and (3) the market to which entry will be impeded must be highly concentrated. As a practical matter, few mergers will ineet these preconditions, but those few would also have been unlawful under the older "foreclosure" theories. This is because foreclosure reappears as the first Guideline precondition, even though it is not so denominated. As envisioned by the Guidelines, a merger would not create the need for two-level entry so long as sufficient unintegrated capacity remained in each market to service two efficientsized plants in the other market. That is, unintegrated firms must not have been foreclosed froin access to suppliers or purchasers. The

100. See, e.g., 4 P. AREEDA \& D. TURNER, supra note 71, I 1004; R. BORK, supra note 36, at 225-38; R. POSNER, supra note 37, at 196-201.

101. Ford Motor Co. v. United States, 405 U.S. 562 (1972).

102. Harnischfeger Corp. v. Paccar, 474 F. Supp. 1151 (E.D. Wis.), affd mem., 624 F.2d 1103 (7th Cir. 1979). Other target companies in contested tender offer settings have met with less success in bringing vertical cases. See, e.g., Carrier Corp. v. United Technologies Corp., 1978-2 Trade Cas. (CCH) I] 62,393 (N.D.N.Y. 1978).

103. See Fruehauf Corp. v. FTC, 603 F.2d 345 (2d Cir. 1979); United States v. Haminermill Paper Co., 429 F. Supp. 1271 (W.D. Pa. 1977).

104. E.g., Dale, Justice Eyes New Criteria for Merger Enforcement, Legal Tiunes (Washington), Dec. 21, 1981, at 24, col. 1; Previews of Merger Guidelines, Uncertainties in Counseling Dominate Antitrust Spring Meeting, 42 ANTITRUST \& TRADE REG. REP. (BNA) No. 1059, at 728 (Apr. 8, 1982); Baxter Defends His Competition Policies: Faculty Urges Caution, Antitust Counseling, 42 Antitrust \& TRADe Reg. ReP. (BNA) No. 1055, at 513 (Mar. 11, 1982). 
Guideline tests are more stringent than the old case law, both as to the necessary degree of foreclosure and as to nonforeclosure elements, which must also be satisfied. Nonetheless, the Guidelines are likely to lead to more vigorous enforcement activity in this area. The old foreclosure theory had been largely discredited in the view of academics and policy makers. By repackaging the theory and shifting its context, the Guidelines have lent it new respectability.

The Guidelines adopt two other theories by which to challenge vertical mergers in certain circumstances: (1) the merger may facilitate collusion by increasing opportunity to monitor competitors or by eliminating a disruptive buyer, and (2) the merger may facilitate evasion of rate regulation. These theories are reasonable statements of policy and are not wholly unrelated to various concepts that have long been present in the antitrust area. ${ }^{105}$ But they are entirely new to vertical merger law. Unlike the Guidelines' provisions addressing, say, market definition and horizontal effects, whose twists and departures from the case law are more in the nature of tinkering adjustments, these two vertical theories attempt to fashion rules of law where none have existed before. A government cliallenge under either theory, if argued in the same ternns as the Guidelines, could well face serious difficulty in the courts.

\section{Conglomerate Mergers}

As with vertical mergers, challenges to conglomerate mergers have long been in decline, and niost theories of conglomerate violation have fallen into disfavor and disuse. In particular, the reciprocity ${ }^{106}$ and entrenchment ${ }^{107}$ theories have withered away. The potential competition theory has continued to enjoy limited vitality, but has been invoked only rarely.

The new Guidelines adopt a similar pattern. The make no mention of reciprocity and entrenchment, accurately reflecting the unwillingness of several successive administrations to bring such cases. They do endorse the potential competition theory for application in limited circumstances, but do not altogether matcli the case law on the point.

The case law treats potential competition as two distinct theoriesperceived potential competition and actual potential competition-and imposes different elements for each. In order to prevail under a perceived potential competition theory, the government must estabhisl

105. Elimination of disruptive elements, for example, has long been viewed with disapproval in the horizontal context. See, e.g., 1968 Guidelines, supra note 2, para. 8, 2 TRADE REG. REP. $(\mathrm{CCH})$ at 6884.

106. See FTC v. Consolidated Foods Corp., 380 U.S. 592 (1965).

107. See FTC v. Procter \& Gamble Co. (Clorox), 386 U.S. 568 (1967); General Foods Corp. v. FTC, 386 F.2d 936 (3d Cir. 1967), cert. denied, 391 U.S. 919 (1968). 
that (1) "the number of potential entrants [is] not so large that the ehmmation of one would be insignificant," "108 (2) "the target market is substantially concentrated," 109 (3) "the acquiring firm has the characteristics, capabilities, and economic incentive to render it a perceived potential de novo entrant," 110 (4) "the acquiring firm's premerger presence on the fringe of the target market in fact tempered oligopolistic behavior on the part of existing participants in that market,"111 and (5) "there are dominant participants in the target market engaging in interdependent or parallel behavior and with the capacity effectively to determine price and total output of goods or services."112 Perceived potential competition cases since Marine Bancorporation have tended to focus upon the fourth ${ }^{13}$ and fifth $^{114}$ elements.

The elements (and indeed the mere validity) of an actual potential competition case are inore difficult to spell out, since the Supreme Court has twice passed up opportumities to endorse the theory. ${ }^{115}$ Nonetheless, the Court has identified two "essential preconditions" to application of the theory, assuming that it is valid: (1) the company must have feasible available means of entering the market, and (2) "those ineans offer a substantial likelihood of ultimately producing deconcentration of that inarket or other significant procompetitive effects." 116

The Guidelines present a third, hoinogenized approach that neglects the difficult eleunents in the case law. ${ }^{117}$ The approach evaluates both actual potential competition and perceived potential competition under a single test of tests that are frained in structural terins. The preconditions to a challenge are as follows: (1) the market must be highly concentrated, (2) entry into the market must not be generally easy, (3) the acquiring firm must have some entry advantage not widely

108. Clorox, 386 U.S. at 581.

109. United States v. Marine Bancorp., 418 U.S. 602, 624 (1974). This is taken as an indicator of current noncompetitive performance and may be rebuttcd by a sliowing of actual market behavior. Id. at 631 .

110. Id. at $624-25$.

111. Id. at 625 .

112. Id. at 630 .

113. See United States v. Siemens Corp., 621 F.2d 499 (2d Cir. 1980); United States v. Consolidated Foods Corp., 455 F. Supp. 108 (E.D. Pa. 1978).

114. See United States v. Black \& Decker Mfg. Co., 430 F. Supp. 729 (D. Md. 1976); United States v. Hughes Tool Co., 415 F. Supp. 637 (C.D. Cal. 1976).

115. Marine Bancorp., 418 U.S. at 625; United States v. Falstaff Brewing Corp., 410 U.S. 526 , 537 (1973).

116. Marine Bancorp., 418 U.S. at 633.

117. "Because of the close relationship between perceived potential competition and actual potential competition, the Department will evaluate mergers that raise either type of potential competition concern under a smgle structural analysis . ..." Guidelimes § IV(A)(3), 47 Fed. Reg. at 28,499, 71 CALIF. L. Rev. at 661. 
shared by other firms, ${ }^{18}$ and (4) the market share of the acquired firm must not be insubstantial. All of these elements find some support in the case law, although to varying degrees. But the Guidelines' elements hardly embody the case law. Taken together, they are insufficient to establish a potential competition case, principally because they fail to inquire into the effects that the potential entrant may have on the market. ${ }^{119}$ As the Guidelines declare, theirs is a structural analysis. The case law, however, has grown to emphasize behavioral analysis: actual market perceptions and conduct have been the battleground in potential competition cases since Falstaff ${ }^{120}$ and Marine Bancorporation. Inasmuch as the Department is invariably a plaintiff, its effort to adopt a structural analysis (and perhaps to encourage courts to do likewise), is understandable. Because the potential competition case law currently lacks structural presumptions such as those introduced into horizontal merger analysis by Philadelphia National Bank, plaimtiffs must still try to prove market effect from scratch on a case-by-case basis. As a result, the key reality of potential competition cases is that they are especially difficult to win. Although the theory contmues to be accepted in principle, ${ }^{121}$ the plaintiff generally loses unless it can find compelling evidence of reasonably short-run market effect. ${ }^{122}$ The outcome of potential competition cases has increasingly turned on the existence of "hot documents"-a smoking gun-showing that entry was planned or that the threat of entry was perceived in the market.

It may be that the potential competition doctrine will be successfully invoked unost often by parties already in a vertical relationship. It inay in those circumstances be possible to limit the group of potential entrants imto the backward or forward market to those who are already in the other market; and the "make or buy" type of analysis that goes on in many vertical contexts may provide the government with enough

118. "The Department is unlikely to challenge a potential competition merger if the entry advantage ascribed to the acquiring firm . . . is also possessed by three or more firms." Id. $\S \operatorname{lV}(\mathrm{A})(3)(\mathrm{c}), 47 \mathrm{Fed}$. Reg. at 28,500, 71 CALIF. L. ReV. at 661. This idea of a small pool of potential entrants has always been central to potential competition analysis, bnt the leading cases have not articulated a precise number. Id., 47 Fed. Reg. at 28,500, 71 CALIF. L. REv. at 661-62.

119. Both the perceived and actual potential competition theories require some proof of market effect, but they differ as to the nature and timing of that effect. Under perceived potential competition, one must show a present market effect brought about by existing oligopolists' tempering their behavior. See, e.g., Brodley, Potential Competition Under the Merger Guidelines, 71 CALIF. L. REv. 376, 379-80 (1983). In contrast, under actual potential competition, one must show a future market effect brought about by the actual entrance of the potential competitor. $I d$. at 379 80.

120. 410 U.S. 526 (1973).

121. See Mercantile Tex. Corp. v. Board of Governors of Fed. Reserve Sys., 638 F.2d 1255 (5th Cir. 1981).

122. See Yamaha Motor Co. v. FTC, 657 F.2d 971 (8th Cir. 1981), cert. denied, 102 S. Ct. 1768 (1982). 
evidence to establish a current market effect. Over all, it would seem that particular market contexts and evidence may have more to do with how potential competition cases come out in the future than does the kind of broad structural analysis set out in the Guidelines.

\section{Defenses}

The Guidelines discuss the "efficiency" and "failing company" defenses to an otherwise unlawful merger. The result is somewhat surprising. While the Guidelines' position on defenses hews especially close to the case law (a unique treatment within the document), it deviates from the Departinent's prior enforcement practice.

\section{Efficiency Defense}

Although a merger defense based upon efficiencies has been a fertile source of academic discussion, ${ }^{123}$ it has found no explicit judicial support. The Guidelines permit consideration of such a defense, but are far froin hospitable. ${ }^{124}$ Indeed, the result under the Guidelines in a given instance is likely to be the same as that under the case lawrejection of the defense. But the case law and the Guidelines differ significantly as to the foundation for their views.

The case law has traditionally based its rejection of the defense on congressional intent. In FTC v. Procter \& Gamble Co. ${ }^{125}$ the Supreme Court stated: "[p]ossible economies cannot be used as a defense to illegality. Congress was aware that some mergers which lessen competition inay also result im economies but it struck the balance in favor of protectimg competition."126 Were this the ouly basis for rejecting the efficiency defense, the defense might be alive and thriving today. As we have seen, section 7 enforcement patterns and case law lave noved

123. See, e.g., Fisher \& Lande, Efficiency Considerations in Merger Enforcement (unpublished inanuscript forthcoming in 92 Yale L.J. - $\rightarrow$ ) (on file with California Law Review); Williamson, Economies as an Antitrust Defense Revisited, 125 U. PA. L. REv. 699 (1977).

124. Guidelines $\S \mathrm{V}(\mathrm{A}), 47$ Fed. Reg. at 28,502, 71 CallF. L. REv. at 665.

125. 386 U.S. 568 (1967).

126. Id. at $\mathbf{5 8 0}$ (citation omitted). A similar thought was advanced even more strikingly in Philadelphia Nat'l Bank, 374 U.S. at 371:

We are clear, . . . that a merger the effect of which "inaybe substantially to lessen competition" is not saved because, on some ultimate reckoning of social or economic debits and credits, it may be deemed beneficial. A value choice of such magnitude is beyond the ordinary limits of judicial competence, and in any event has becn made for us already, by Congress when it enacted the amended $\$ 7$. Congress determined to preserve our traditionally competitive economy. It therefore proscribed anticompetitive mergers, the benign and the nialignant ahke, fully aware, we must assume, that some price might have to be paid.

See also Brown Shoe, 370 U.S. at 344 ("It is competition, not competitors, which the Act protects."). But see United States v. Consolidated Foods Corp., 455 F. Supp. 108, 137 (E.D. Pa. 1978) (acquisition of firm with related technology may increase competition by permitting acquiror to niarket truly competitive product). 
steadily over the course of their evaluations away from Congress's intent in 1950. But rejection of the efficiency defense is also consistent with an economic foundation for antitrust policy. Plausible efficiencies can normally be realized through internal expansion, without risking a reduction in the vigor of competition, rather than through mergers. And the statistical thresholds that trigger a challenge by enforcement authorities can be set sufficiently high to permit realization of available efficiencies in most cases.

The Guidelines' approach rests on such an economic foundation, perhaps buttressed by concerns over efficient use of limited enforcement resources. As the Guidelines recognize, efficiencies are easier to allege than to prove, and their magnitudes are difficult to determine. Consequently, the Guideline position is extremely strict. ${ }^{127}$ For the Department to consider an efficiency claim, a merger must satisfy several demanding preconditions; ${ }^{128}$ even then, the Department will regard the efficiencies only as a "mitigating factor," rather than as a bar to enforcement. The net result is an articulated enforcement policy based upon economic and managerial concepts, but consistent with the teachings of populist case law.

Notwithstanding the tough talk, however, the Department's actual practices are more tolerant. The Department does consider efficiency claims when exercising its prosecutorial discretion, and Assistant Attorney General Baxter has implicitly recognized efficiencies by suggesting that opposition to a merger by coinpetitors may reflect their concern

127. In contrast, the FTC is considerably more open than the Department to efficiency evidence. In its view, certam classes of efficiencies are "appropriate for consideration by the agency in the exercise of its prosecutorial discretion at the precomplaint stage." FTC Statement, supra note 86 , § IV, TRADE REG. REP. (CCH) No. 546, at 81. The Commission apparently will limit its inquiry "to measurable operating efficiencies, such as production or plant economies of scale," $i d$., and will not consider efficiencies that "flow from factors peculiar to the merged firms, such as improved quality of inanagement." Id. n.20, TRADE REG. REP. (CCH) No. 546, at 81 n.20.

The FTC would not go so far as to establish an efficiency defense in the literal sense. "[T]here are too many analytical ambiguities associated with the issue of efficiencies to treat it as a legally cognizable defense." Id. § IV, TRADE REg. REP. (CCH) No. 546, at 81. Chairman Miller, however, dissents from this view and would recognize the defense at the adjudication stage. Id. n.22, TRADE Reg. ReP. (CCH) No. 546, at $81 \mathrm{n} .22$.

Even while opening the door to efficiency considerations, the Commission remains skeptical of efficiency claims. See Interview with Robert Tollison, FTC's Chief Economist, 43 ANTITRUST \& Trade Reg. ReP. (BNA) No. 1083, at 611-12 (Sept. 30, 1982).

128. Although the Guidelines are not entirely clear on the poimt, the preconditions appear to be as follows: (1) the case must be close prior to consideration of efficiencies; (2) evidence must satisfy a "clear and convincing" standard; (3) substantial cost savings must result from scale economies, integration of production facilities, or multiplant operations; (4) one or more firms in the industry must already enjoy such efficiencies; and (5) equivalent results could not be achieved within a comparable period of time through internal expansion or a less anticompetitive merger. Guidelines § V(A) n.53, 47 Fed. Reg. at 28,502 n.53, 71 CALIF. L. REv. at 665 n.53. 
over mcreased competition. ${ }^{129}$ Efficiencies will not save mergers that are otherwise clearly unlawful, but they may tip the balance in close cases.

\section{Failing Company Defense}

Unlike the efficiency defense, the failing company defense was created by the courts and has been approved by. Congress. ${ }^{130}$ Nonetheless, the doctrine has rarely been litigated successfully. More often, it has served to deter prosecution. As a result, the defense is widely recognized to be more useful as a practical tool in mfluencing prosecutorial discretion than in persuading a tribunal.

The failing company defense apparently traces back to American Press Association v. United States, ${ }^{131}$ but it was first clearly articulated by the Supreme Court in International Shoe Co. v. FTC. ${ }^{132}$ As the case law has evolved since that time, it has continued to accept the failing coinpany defense, but only grudgingly. Under the leading case of Citizen Publishing Co. v. United States, ${ }^{133}$ application of the doctrine seems to require satisfaction of three elements: (1) one of the companies imvolved in the inerger must face the "grave probability of a business failure"; 134 (2) the prospects of reorganization in bankruptcy must be dim or nonexistent,; ${ }^{135}$ and (3) the acquiring company must be the least anticompetitive purchaser. ${ }^{136}$ Nonetheless, the contours of these elements are far from clear. There is a split of authority, for example, over whether dim reorganization prospects constitute a separate element. ${ }^{137}$ Much of the confusion apparently stems from the fact that Supreme Court opinions subsequent to Citizen Publishing do not refer to a dim reorganization prospects element. ${ }^{138}$

Similarly, there is confusion over the availability of acceptable alternative purchasers. While the case law, includimg Citizen Publishing, speaks as if the prospective purchaser must be the only available pur-

129. See Federal Antitrust Policy: Implications for Small Business, Hearings Before the Subcomm. on Productivity and Competition of the Sen. Comm. on Small Business, 97th Cong., 1st Sess. 111 (1981) (testimony of William F. Baxter).

130. See S. REP. No. 1775, 81 st Cong., 2d Sess. 7, reprinted in 1950 U.S. CODE CoNo. \& AD. NEws 4293, 4299.

131. 245 F. 91 (7th Cir. 1917).

132. 280 U.S. 291 (1930).

133. 394 U.S. 131 (1969).

134. Id. at 137 (citation omitted).

135. Id. at 138.

136. Id.

137. Compare United States Steel Corp. v. FTC, 426 F.2d 592, 606 n.30, 609-10 (6th Cir. 1970) (FTC finding madequately supported where FTC failed to consider how firm would have fared im reorganization) with United States v. M.P.M., Inc., 397 F. Supp. 78, 96-97 (D. Colo. 1975) ("dim reorganization" interpreted as alternative to "no other available purchaser").

138. See, e.g., United States v. Greater Buffalo Press, Inc., 402 U.S. 549 (1971). 
chaser, most other authority prefers the formulation that the prospective purchaser must be the least anticompetitive purchaser. ${ }^{139}$

The Guidelines articulate a failing company defense that tracks the mainstream view of the case law. ${ }^{140}$ This approach essentially repeats the Department's 1968 formula on failing conpanies. If this is indeed the Department's current position, it represents a backward step fron the considerable evolution that the Department's thinking had undergone in the intervening years. ${ }^{141}$ By the late 1970's, the Department was applymg a sliding scale to failing company claims-the stringency with which the elements of the test were applied depended on the coinpetitive state of the market involved. In structurally competitive markets, the Department often reacted to claims of "hurting (but less than failing) companies" and threats of plant shutdowns by exercising its prosecutorial discretion not to sue. In some imstances, the Department's willingness may have reflected political concerns as much as antitrust theory-closed plants yield unemployed and hence disgruntled constituents - but purely political decisions not to prosecute were more often imposed upon the Division by the Attorney General's office. ${ }^{142}$

A related issue concerns the Department's treatment of failing divisions of otherwise healthy companies. The Guidelines state that "the Department will recognize the defense in appropriate cases," 143 but this statement is confusing to one attempting to parse the Guidelines. Given the Guidelines' standards for failing companies-and particularly the element calling for dim reorganization prospects-it is difficult to imagime a situation in which a failing division defense will be accept-

139. But see Dep't of Justice, Sale of Television Business-Motorola and Matsushita, 5 TRADE REG. REP. (CCH) IT 50,209, 50,212 (Apr. 23 \& May 20, 1974).

140. The Department states that it is unlikely to challenge an anticompetitive merger in which one of the merging firms is allegedly failing when: (1) the allegedly failing firm probably would be unable to ineet its financial obligations in the near future; (2) it probably would not be able to reorganize successfully under Chapter XI of the Bankruptcy Act; and (3) it has made unsuccessful good faith efforts to elicit reasonable alternative offers of acquisition of the failing firm that would both keep it in the inarket and pose a less severe danger to competition than does the proposed merger. Guidelines \& V(B), 47 Fed. Reg. at 28,502, 71 CaLIF. L. Rev. at 665-66. The FTC's stance on the failing company defense appears to be more tolerant than the Justice Department's. Cf. FTC Statement, supra note 86, § V, TRADE REG. REP. (CCH) No. 546, at 82-83 (factors considered by FTC in exercising its prosecutorial discretion).

141. Nonetheless, a new tough stance would not be altogether surprising, given Assistant Attorney General Baxter's views on the subject. Indeed, if the failing company defense were not explicitly sanctioned in the case law, Baxter might have rejected it altogether. Some indication of the severity of his view may be found in his remarks last year before the ABA Antitrust Section: "[M]y reaction is to be very, very negative, very hostile, because the more I think about it, the less I see any important economic justification for the very existence of this [failing company] doctrine . . . Baxter, Remarks: The Failing Firm Doctrine, 50 AnTITRuST L.J. 247, 251-52 (1982).

142. One example is provided by the Lykes-LTV merger. See generally N.Y. Times, June 22 , 1978, at 1, col. 6.

143. Guidelines $\S \mathrm{V}(\mathrm{B}), 47$ Fed. Reg. at $28,502,71$ CALIF. L. REV. at 666. 
able to the Department. On the other hand, the fact that the Department recognizes a failing division defense suggests that perhaps its strict statements on the failing company defense should not be taken literally. This anbiguity will remain until either the Department issues further express guidance, or an enforcement pattern develops.

The ambiguity is understandable, for, as the Guidelines forthrightly note, the failing company defense is an ambiguous doctrine whose original basis is open to question. ${ }^{144}$ The Guidelmes seem to adopt the view that the financial health of the firm is relevant to the competitive analysis. When the elements of the defense are satisfied, the failing firm is presumed to have such slight competitive significance that its elimination by merger would not substantially lessen competition.

If the Guidelines do in fact adopt such a view, their next stepwholesale incorporation of the traditional test-is curious. In a docuinent so tinged with thoughtful analysis and broad discretion, the strict approach of the case law, sounding unore like a toggle switch than a spectrum, seeins terribly incongruous, for the competitive significance of a failing firm will hinge on numerous factors best characterized by sliding scales. Without trying to be exhaustive, one would think we should be more lement (1) in structurally competitive industries than in highly concentrated industries; (2) towards mergers that only shightly overstep the Guidelines' enforcement thresholds than towards mergers that overstep substantially; (3) where assets of the failing firm are relatively immobile and indivisible; and (4) where the products of the failing firm require substantial post-sale service. The first two points are fairly obvious and reflect the Departinent's practices in the late 1970's. The last two points handicap the likelihood of successful reorganization.

\section{CONCLUSION}

The 1982 Merger Guidelines reconcile many of the inconsistencies and span many of the gaps that have developed in merger law since the passage of the Celler-Kefauver Amendments in 1950. In so doing, however, the Guidelines necessarily deviate from the preexisting case law in numerous particulars. They thus risk rejection by the courts.

The day has long passed smce the primcipal consistency of merger hitigation was that "the Government always wins." 145 That former reality had given the 1968 Merger Guidelines a special importance. Today, in contrast, the government must persuade a trier of fact of the hikely

144. Id. $\S \mathrm{V}$ (B) \& n. 54,47 Fed. Reg. at 28,502 \& n.54, 71 CALIF. L. Rev. at 665 \& n.54.

145. United States v. Von's Grocery Co., 384 U.S. 270, 301 (1966) (Stewart, J., dissenting). 
anticompetitive effect of a challenged merger in a defined market-and it must do so on hard evidence. Whether the 1982 Guidelines will help the government win the cases it chooses to bring remains an open question. A busy trial judge may look upon the Guidelines as the work of an institutional advocate, rather than of a philosopher-king. This may inean that the Guidelines' candid statements can be wielded more effectively by defendants than by the government.

As of this writing, the Antitrust Division has litigated only two merger cases under the theories articulated in the 1982 Guidelines. ${ }^{146}$ In both it was soundly trounced. Those cases may or may not prove representative. Perhaps the appellate courts will embrace the Guidelines' basic methodology; if so, the Guidelines will have substantial influence on the future development of merger law. On the other hand, the Guidelines may prove too coinplex and sophisticated for most judges; in that case, their influence will probably be ininor.

The latter possibility would often be unfortunate, for most of the Guidelines' deviations from preexisting law constitute an effort to distill a consistent analytical framework from both tortuous precedent and trends in economic thought. This is not to argue that each Guideline provision is justified by the entirety, nor that the evidentiary problems presented by the Guidelines should be trivialized. But, as a general inatter, courts could do far worse than to defer to these Guidelines, just as they have deferred to predecessor guidelines in the past.

146. Both coinplaints reflected the basic Guidelines' methodology, although they were filed shortly before the Guidelines were formally issued on June 14, 1982. Both presumably rested on the Antitrust Division's determination that it could satisfy its own inarket definition tests.

In United States v. ARA Servs., 5 Trade REg. ReP. (CCH) 1 50,818 (S.D. Ohio Apr. 29, 1982), the government challenged a merger between two industrial linen supphers operating in various local markets in Ohio and West Virginia. The complaint alleged HHI imcreases ranging from 245 to $1110 \mathrm{~m}$ the various markets alleged. The defendants responded that there was great supply elasticity, since an industrial hinen suppher was nothing more than a commercial laundry which also rented linen. The trial judge, apparently accepting the defendants' market approach, dismissed the government's request for a preliminary injunction. The case was ultimately settled.

In United States v. Virginia Nat'1 Bankshares, Inc., 1982-2 Trade Cas. (CCH) ๆ 64,871 (W.D. Va. June 21, 1982), the Antitrust Division challenged a merger of two banking organizations located in a remote inountamous county in southwestern Virginia. The government alleged that the two banks were horizontal competitors, despite the fact that they were eight miles apart on the opposite sides of a inountain, and calculated $\mathrm{HHI}$ increases of more than 300 points. The government tried to prove its case by offering surveys in which bank customers were asked to state their response to a five percent price rise. The district judge, sitting in Big Stone Gap, Virginia, rejected the government's proof and concluded that the two banks were in separate geographic inarkets. See Wertheimer, DOJ Tries Out Its 5-Percent Geographic Market Test, Legal Times (Washington), Aug. 30, 1982, at 17, col. 1 . 